\title{
Pemikiran Harun Yahya Dalam Nilai Nilai Moral Al-Qur'an ( Studi Analisis Nilai Nilai Pendidikan Akhlaq)
}

\author{
Ali Mustofa \\ Dosen Sekolah Tinggi Ilmu Tarbiyah Al Urwatul Wutsqo Jombang, Indonesia \\ Email: aljep_90@yahoo.com
}

\begin{abstract}
Moral education is a sub / part of the subject of Religious Education, because the real religion is morality, so that the presence of the Prophet Muhammad to the face of the earth was in the step of completing the morals of men who at that time, girls were killed alive, against the truth of many who resist, as well as many other levels of munkar they do. Because religion is morals, it is not excessive to say that what is good according to morals is good also according to religion. Because so much the role of education of Morals in the formation keperibadian son of man then all Muslim philosophers agree that moral education is the soul of Islamic education, because the highest goal of Islamic education is to educate the soul and morals. The values of moral education in the book value of moral values of the Qur'an on Islamic education based on human life together with what He has created. The Qur'an tells people to be dignified, humble, trustworthy, kind, faithful, adult, and willing to listen to goodness. values of moral education contained in the book "the moral value of the Qur'an The work of Harun Yahya is: belief in the existence of God, Godly to Allah, belief in the fate of Allah, faith in God, Pray, Believe, Be patient, grateful, despair, mercast, humble to God, read the Qur'an, take refuge in God, humble, do not make fun of.
\end{abstract}

Key words: moral values 
Konteks Penelitian

Pendidikan adalah usaha sadar dan terencana untuk mewujudkan suasana belajar dan proses pembelajaran agar peserta didik secara aktif mengembangkan potensi dirinya untuk memiliki kekuatan spiritual keagamaan, pengendalian diri, keperibadian, kecerdasan, akhlaq mulia, serta keterampilan yang diperluakan dirinya, masyarakat, bangsa dan negara.(Undang-undang RI Nomor 20 Tahun 2003) Pendidikan pada umumnya berarti daya upaya untuk memajukan budi pekerti (karakter, kekuatan bathin), pikiran (intellect) dan jasmani anak-anak selaras dengan alam dan masyarakat.(http://www.artikelbagus .com/2012)

Menurut H. M Arifin, pendidikan adalah usaha orang dewasa secara sadar untuk membimbing dan mengembangkan kepribadian serta kemampuan dasar anak didik baik dalam bentuk pendidikan formal maupun non formal.(Arifin, 1976, p.12) Adapun menurut Ahmad D. Marimba adalah bimbingan atau pimpinan secara sadar oleh si pendidik terhadap perkembangan jasmani dan rohani si terdidik menuju terbentuknya kepribadian yang utama.( Marimba, 1989, p.19) Pendidikan memiliki proses karakter bangsa untuk meningkatkan kualitas kehidupan masyarakat dan bangsa dimasa akan datang dalam proses pendidikan karakter bangsa secara aktif anak didik mengembangkan potensidirinya melakukan proses interalisasi dan penghayataan nilainilai menjadi kepribadian masyarakat yang lebih sejahtera serta mengembangkan kehidupan bangsa yang bermanfaat.( Wayan Lasmawan, 2004, p.4) Dari beberapa pendapat yang telah diuraikan secara terperinci dapat disimpulkan bahwa pendidikan pada hakekatnya merupakan usaha manusia untuk dapat membantu, melatih, dan mengarahkan anak melalui transmisi pengetahuan, pengalaman, intelektual, dan keberagamaan orang tua (pendidik) dalam kandungan sesuai dengan fitrah manusia supaya dapat berkembang sampai pada tujuan yang dicita-citakan yaitu kehidupan yang sempurna dengan terbentuknya kepribadian yang utama.

Di samping itu, pendidikan merupakan usaha sadar untuk mengembangkan individu secara penuh tersebut, merupakan syarat akan norma dan nilai-nilai. Oleh karena itu, norma dan nilai-nilai menjadi penting dalam semua perencanaan pendidikan. Islam memberikan suatu norma obyektif tersebut, yang bersumber pada AlQur'an dan al Hadits.(Ramayulis, 2004, p.16) Dalam Islam, tidak hanya disiplin ilmu yang terpisah dari etika Islam. Dan pentingnya komparasi antara akal dan wahyu dalam menentukan nilai-nilai moral. Salah satu nilai yang utama yaitu akhlak (karakter). Abdul majid et. al, 2004, p.58)

Nilai artinya sifat-sifat (halhal) yang penting atau berguna bagi kemanusiaan.(Purwadarminta, 1999, p.677) Nilai itu praktis dan efektif dalam jiwa dan tindakan manusia dan melembaga secara obyektif di dalam masyarakat.( Titus, M.S, et al, 
1984, p.122) Nilai merupakan petunjuk-petunjuk umum yang telah berlangsung lama yang mengarahkan tingkah laku dan kepuasan dalam kehidupan sehari-hari. Selain itu, nilai dapat dikatkan sebagai sesuatu yang berharga, bermutu, menunjukkan kualitas, dan berguna bagi manusia. Sesuatu itu bernilai berarti sesuatu itu berharga atau berguna bagi kehidupan manusia. Persahabatan sebagai nilai (positif/baik) tidak akan berubah esensinya manakala ada pengkhianatan antara dua yang bersahabat. Artinya nilai adalah suatu ketetapan yang ada bagaimanapun keadaan di sekitarnya berlangsung.

Pendidikan Akhlak adalah merupakan sub/bagian pokok dari materi pendidikan agama, karna sesungguhnya agama adalah akhlak, sehingga kehadiran Rasul Muhammad ke muka bumi pun dalam rangka menyempurnakan akhlak manusia yang ketika itu sudah mencapai titik nadir. Anak perempuan dibunuh hidup-hidup, fanatisme kesukuan mendarah daging, terhadap kebenaran banyak yang melawan, serta terlalu banyak tingkat kemungkaran lain yang mereka lakukan. Karna agama adalah akhlak, maka tidak berlebihan kiranya jika dikatakan bahwa apa yang baik menurut akhlak adalah baik pula menurut agama. Karena begitu besar peran pendidikan akhlak dalam pembentukan keperibadian anak manusia maka semua filusuf muslim sepakat bahwa pendidikan akhlak merupakan jiwa pendidikan Islam, karna tujuan tertinggi dari pendidikan Islam adalah mendidik jiwa dan akhlak.(Juwariyah, 2010, p.96)

Akhlak merupakan mustika hidup yang membedakan makhluk manusia dari makhluk hewani. manusia tanpa akhlak, akan kehilangan derajat kemanusiaannya sebagai makhluk Tuhan yang paling mulia, dan meeluncur turun kederajat binatang. Dan manusia yang telah membinatang ini, sangat berbahaya. Ia akan lebih jahat dan lebih buas dari pada binatang buas sendiri.(Humaidi Tatapangarsa, 1990, p.13) Untuk itu sangat pentingnya akhlak mulia pada anak manusia.

Al-Qur'an sebagai wahyu Allah yang sempurna tidak bisa kita amalkan sebelum kita melakukan kajian secara mendetail dan mendalam. Selama ini Al-Qur'an di kaji sebagai ayat-ayat AlQur'anologi saja. Mahasiswa belajar Al-Qur'an agar bisa menjawab soal, menghafal ayat-ayat Al-Qur'an sebatas memenuhi tugas guru. Namun sebenarnya lebih jauh dari itu Al-Qur'an tidak hanya di pelajari tetapi perlu di amalkan dalam kehidupan sehari-hari.

Pendidikan akhlak menurut al Qur'an lebih ditekankan pada orang agar mempraktikkan dan mengamalkan nilai-nilai yang baik dan menjauhi nilai-nilai yang buruk dan ditujukan agar manusia mengetahui tentang cara hidup, atau bagaimana seharusnya hidup; karakter (akhlak) menjawab pertanyaan manusia tentang manakah hidup yang baik bagi manusia, dan bagaimanakah seharusnya berbuat, agar hidup memiliki nilai, kesucian dan kemuliaan. 
Tingginya kedudukan pendidikan karakter/akhlak menurut al Qur'an dapat pula dilihat dari banyaknya ayat-ayat al Qur'an yang berkaitan dengan akhlak. Menurut hasil penelitian terdapat seperempat ayat dalam al Qur'an yang berhubungan dengan akhlak, baik dari segi teori atau dari segi praktis. Pendapat tersebut di atas lebih lanjut dapat dilihat dari seluruh aspek ajaran Islam yang disebut dalam al Qur'an yang di dalamnya terdapat nilai-nilai pendidikan karakter. Ajaran Islam tentang keimanan misalnya selalu di hubungkan dengan amal shaleh (akhlak).(Humaidi Tatapangarsa, 1990, p.170) Allah mengutus para Rasul untuk membawakan petunjuk agar selamat dunia dan akhirat serta mencontohkan teladan yang baik seperti Nabi Muhammad SAW, yang mendapat sebutan "Uswatun Khasanah" (tauladan yang baik) sebagaimana firman Allah dalam al Qur`an Surat al Ahzab ayat 21. (Humaidi Tatapangarsa, 1990, p.420)

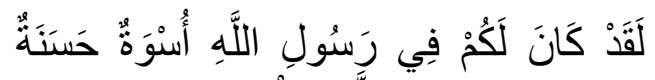

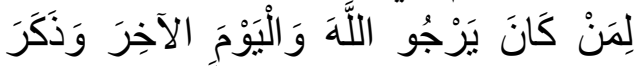

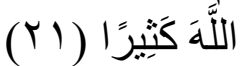

Artinya:Sesungguhnya telah ada pada (diri) Rasulullah itu suri teladan yang baik bagimu (yaitu) bagi orang yang mengharap (rahmat) Allah dan (kedatangan) hari kiamat dan Dia banyak menyebut Allah.(QS. Al-Ahzab)(AlQur'an Terjemah Depag)

Allah mengutus Nabi Muhammad sebagai Nabi yang terakhir yang dimana untuk memperbaiki Akhlak. Lebih lanjut pendidikan karakter juga terkait dengan tiga matra pendidikan, yaitu pendidikan individual, pendidikan sosial dan pendidikan moral. Untuk mewujudkan visi, misi dan tujuan tersebut, pendidikan karakter membutuhkan dukungan dari pendidikan moral, pendidikan nilai, pendidikan agama dan pendidikan kewarganegaraan.

(Al-Qur'an

Terjemah Depag)

Modernisasi saat ini telah memberikan implikasi yang luar biasa bagi kehidupan umat manusia. Pada satu sisi, kemajuan dalam segala bidang yang terjadi saat ini dapat mendatangkan dampak positif bagi peradaban manusia,namun pada sisi lain tidak dapat dipungkiri membawa dampak negatif. Dampak positif dari kemajuan yang semakin pesat seperti sekarang ini mampu membawa manusia menyelesaikan persoalan hidupnya melalui sarana kemajuan teknologi, sedangkan dampak negatif yang muncul bersamaan dengan perkembangan ilmu pengetahuan dan teknologi yaitu dapat menjerumuskan manusia pada kenestapaan, kegersangan moral spiritual.

Fenomena yang nyata saat ini adalah masyarakat sekarang dihadapkan pada pernmasalahan kemerosotan akhlak yang menyentuh ke segala bidang. Bidang dari kemerosotan tersebut antara lain semakin pudarnya kejujuran, meningkatnya pola hidup individualisme, hedonisme dan semakin langkanya sikap toleransi yang diikat oleh rasa persaudaraan yang menjunjung nilai-nilai kemanusiaan serta tidak luput juga masalah radikalisme dalam realitas 
kehidupan sehari-hari yang hanyaa menyisakan luka dan derita yang begitu memperhatinkan. Kondisi tersebut menjadi hal yang bertambah ironis, ketika kemerosotan akhlak tersebut dilakukan oleh remaja seebagai generasi penerus dan harapan bangsa, Yang merupakan penentu peradaban dan kemajuan bangsa. Hal tersebut terbukti dalam sebuah berita yang termuat dalam Sindonews.Com :

Pelajar SMP Tawuran di Depan Rumah Bupati

SAMPANG - Puluhan pelajar SMP di Kabupaten Sampang, Madura, Jawa Timur, terlibat tawuran di depan rumah dinas (Rumdin) Bupati setempat. Mereka saling serang seperti adu jotos dengan membuka baju.Beruntung aksi tawuran tersebut tidak sampai jatuh korban. Pasalnya, ketika Satpol PP datang ke lokasi untuk menghentikan tawuran, para pelajar langsung semburat untuk menyelamat diri.

Hingga kini, belum diketahui secara pasti motif di balik tawuran antar pelajar. Satpol PP akan memanggil para guru asal pelajar SMP yang tawuran.

Supaya nantinya akan memberikan pembinaan terhadap murid agar tidak tawuran kembali. Karena hal semacam itu merugikan diri sendiri dan merusak citra dunia pendidikan."Ketika kami tiba di lokasi untuk menghentikan tawuran, para pelajar SMPN 1 Sampang langsung kabur semua," terang Penyidik Pegawai Negeri Sipil (PPNS) Satpol PP Sampang Jalil, Senin (8/6/2015). Menurut Jalil, pihaknya sudah menghubungi pihak sekolah. Rencananya, besok akan memanggil sang guru. Kemudian akan melakukan pembinaan pada pelajar supaya tidak mengulangi tawuran."Nanti kami bersama sekolah akan melakukan pembinaan pada siswa," pungkasnya.

Sebagai generasi penerus demi mewujudkan bangsa dan negara yang berperadaban sesuai dengan nilai-nilai Islam serta sesuai keperibadian bangsa, maka dituntut untuk memiilki keperibadian Islam hal itu haruslah memiliki kematangan jiwa, mental dan moralitas.

Untuk dapat meraih kematangan tersebut diperlukan proses yang berkesinambungan dalam mata rantai pendidikan. Dalam hal ini, peserta didik menjadi objek esensial pendidikan yang diharapkan akan benar-benar mampu melaksanakan prinsip-prinsip kemanusiaan dengan cara efektif dan operatif, diantaranya adalah melalui pendidikan Islam.

Media pendidikan sebagai salah satu faktor yang mempengaruhi keberhasialan pendidikan, media pendidikan tersebut bisa menggunakan media cetak maupun media elektronik. media elektronik contohnya televisi, radio, internet dan lainnya, sedangkan media cetak contohnya seperti buku, majalah, komik, novel, puisi, cerpen, surat kabar dan lain-lain. Dari media yang ada, buku menjadi salah satu bentuk karya tulis yang penting untuk dikaji terutama dalam mencari alternatif untuk mengasosiasikan dan menanamkan nilai-nilai pendidikan akhlak. Buku yang dimaksud adalah buku yang berjudul Nilai-Nilai Moral Al-Qur'an karangan Harun Yahya. 
Dalam buku Nilai-Nilai Moral Al-Qur'an karangan Harun Yahya ini berbagai masalah yang berkaitan dengan akhlak dijelaskan berdasarkan ayat-ayat Al-Qur'an. Semua pokok bahasan yang menyangkut ayat-ayat Allah yang dipaparkan sedemikian rupa sehingga tidak menyisakan lagi keraguan atau tanda tanya dalam benak pembaca. Gaya yang tulus, sederhana dan fasih ini dapat dipahami dengan mudah oleh pembaca dari segi umur dan kelompok sosial. Bahkan mereka yang menolak segela sesuatu yang berhubungan dengan agama sekalipun akan berpengaruh oleh fakta-fakta yang dipaparkan serta tak sanggup menyangkalnya isinya.(Harun yahya, 2004, p.i)

Dibanding dengan buku-buku Islami yang lain, buku ini lebih spesifik membahas tentang Akhlak secara terperinci dan lengkap dengan ayat-ayat Al-Qur'an yang berpusat pada satu tujuan yaitu menyampaikan pesan-pesan AlQur'an pada masyarakat. Pembahasan buku-buku tersebut berfokus pada Moral sebagai kajian utamanya, sehingga mempermudah pembaca dalam menggali pengetahuan serta pemahaman masyarakat dalam bermoral, dimana Moral tersebut penuh dengan nilainilai pendidikan akhlak.

$$
\text { Kehidupan manusia }
$$

beragama yang dimana sumber dan pedoman hidupnyaa ialah Al-Qur'an yang dimana Al-Qur'an menginformasikan kepada manusia tentang kebenaran sifat-sifat Allah. Manusia sebagai makhluk Allah yang dimana pada hakikatnya diutus sebagai Khalipah atau pemimpin di bumi ini, meskipun demikian manusia yang diciptakan dengan spesial berbeda dengan makhluk lainnya ini jarang ada yang memegang teguh dan berprilaku/berakhlak sesuai dengan aturan yang telah Allah berikan sebagai pedoman hidup didunia ini meskipun pada hakikat dan tujuan Manusia diciptakan ialah menyembah dan menghamba padaNya dengan tata cara yang Dia kehendaki, dalam buku Nilai-Nilai Moral Al-Qur'an ternyata banyak pelajaran yang dapat diambil untuk kita Manusia asumsi sebagai pijakan dalam kehidupan.

Karena Allah adalah pembuat keputusan, setiap kejadian merupakan anugrah bagi makhlukNya segala sesuatu telah direncanakan untuk kebaikan agama dan untuk kehidupan orang yang beriman di akhirat kelak. Kaum muslimin dapat merujuk pada pengalaman mereka untuk melihat bahwa ada sesuatu yang bermanfaat bagi diri mereka pada akhir sebuah kejadian.

Setiap manusia yang beragama Islam (muslim)maupun bukan Islam (non muslim) pernah mendapat cobaan hidup baik ringan maupun berat, perjuangan hidup, baik dari golongan rendah maupun atas sekalian.Perjuangan hidup tampak tidak menyenangkan akan tetapi, seorang muslim harus mengerti. Bahwa kejadian yang tampak menakutkan akan berakhir dengan kemenangan bagi orang yang ber iman, cepat atau lambat, Alloh akan memberikan kemurahan hatiNya. 
Salah satu contoh yang dapat dikutip dari buku tersebut yaitu ;

Kehidupan Nabi Yusuf as. Adalah salah satu di antara yang luar biasa. Pada masa kecilnya, Nabi Yusuf as, di buang di dasar sumur oleh saudara- saudarnya. Selanjutnya, ia di selamatkan, kemudian di fitnah dan di penjara walaupun ia tidak bersalah. Bagi orang yang tidak ber iman, semua itu disangka kemalangan yang besar. Akan tetapi, Yusuf as, selalu berfikir bahwa hal ini bisa terjadi hanya dengan kehendak Alloh. Dansemua itu pasti akan berubah menjadi yang lebih baik. Ternyata terbukti Alloh mengubah "Bencana" menjadi kebahagiaan. Nabi Yusuf as. Berhasil lolos dari penjara dan pada saat yang bersamaan menjadi gubernur di tempat tersebut.(Harun Yahya, 2004)

Dari contoh kecil kehidupan Nabi Yusuf as, tersebut, yang ternyata dapat mengandung nilainilai pendidikan akhlaq. Kisah-kisah yang ada dalam buku Nilai-nilai Moral Al-Qur'an Harun Yahya tersebut menjadi menarik untuk dikaji karna dapat diketahui bahwa kisah kisah teladan dalam Al-Qur'an dapat diambil pelajaran untuk kita ikuti sebagai jalan menempuh kehidupan duniawi dalam menyongsong kehidupan yang kekal abadi yang bermartabad lurus dan di Ridhoi oleh sang pemilik Kehidupan yakni Allah azzawa jalla.

Selain Nilai-nilai pendidikan akhlak dalam buku tersebut, banyak pula mengandung nilai nilai pendidikan akidah yang mana dapat dikaji pula. mengenai nilai-nilai pendidikan akhlak yang terdapat dalam buku "Nilai-Nilai Moral alQuran" karya Harun Yahya yang dapat digunakan sebagai pengayaan materi untuk menanamkan pendidikan akhlak dan juga untuk mengatasi masalah kemerosotan akhlak pada saat sekarang ini.

\section{Nilai-Nilai Pendidikan Akhlak dalam Buku Nilai Moral Al Qur'an Karya Harun Yahya}

Mencapai suatu akhlak yang sempurna adalah tujuan sebenarnya dari pendidikan. Ahmad D. Marimba mengatakan bahwa tujuan pendidikan adalah identik dengan tujuan hidup seorang Muslim, yaitu menjadi hamba Allah yang mengadung implikasi kepercayaan dan penyerahan diri kepadaNya.(Marimba, 1980, p.48-49)

Undang-Undang sistem pendidikan Nasional berbunyi: Pendidikan Nasional berfungsi mengembangkan kemampuan dan membentuk watak serta peradaban bangsa yang bermartabat dalam rangka mencerdaskan kehidupan bangsa, bertujuan untuk berkembangnya potensi peserta didik agar menjadi manusia menjadi manusia yang beriman dan bertakwa kepada Tuhan yang Maha Esa, berakhlak

mulia,sehat,berilmu,cakap,kreatif,ma ndiri dan menjadi warga negara yang demokratis serta bertanggung jawab. (http://pustakamateri.web.id/undangundang-tentang-sistem-pendidikannasional/ Diakses tanggal 25 mei 2016)

Pendidikan Islam, yang paling utama dan yang harus mendapat perhatian besar adalah 
pendidikan akhlak, sebagaimana telah dikatakan oleh pakar pendidikan M. Athiyah al-Abrosy, yaitu bahwa pembentukan akhlak yang tinggi merupakan tujuan utama dari pendidikan Islam.(Athiyah AlAbrasyi, 1970, p.10) Dalam kamus Besar Bahasa Indonesia pendidikan ialah proses perubahan sikap dan tata laku seseorang atau kelompok orang dalam usaha mendewasakan manusia melalui upaya pengajaran pelatihan.(Kamus Besar Bahasa Indonesia, 1994, p.232)

Pembahasan dalam buku Harun Yahya ini adalah sebagai berikut:

1. Keberadaan Allah.(Yahya, Harun, 2004)

Pokok dari segala pokok akidah adalah beriman kepada Allah SWT.Yang berpusat pada pengakuan terhadap eksistensi dan kemaha Esaan-Nya.Keimanan kepada Allah ini merupakan keimanan yang menduduki peringkat pertama. Dari situ dengan sendirinya akan lahir keimanan pokok-pokok (rukun) iman yang lain. Sepanjang seorang itu beriman kepada Allah, niscaya ia akan beriman kepada para malaikat, kitab suci, para Rasul, hari kiamat, ketentuan baik dan buruk sebab rukun iman yang disebutkan belakangan merupakan cabang dari keimanan kepada allah.( Afif Muhammad, 1996, p.26

Al Qur'an Yang merupakan pedoman hidup yang sangat penting dalam mencapai Allah karna al-Qur'anlah petunjuk yang benar dari Allah SWT. Sebagai mana Allah telah mengimformasikan dalam Qur'an Surat al-Baqarah ayat 255(Harun yahya, 2004, p.7)

Dalam Qur'an Surat athThalaq ayat 12.(Al-Qur'an terjemah Depaq)

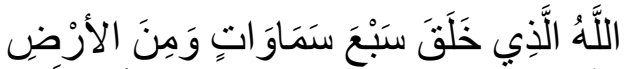

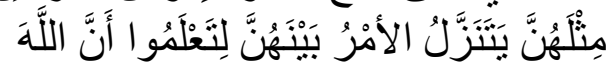

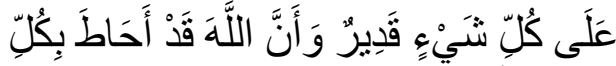

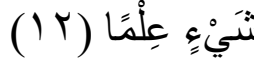
Artinya: "Allah-lah yang menciptakan tujuh langit dan seperti itu pula bumi. perintah Allah Berlaku padanya, agar kamu mengetahui bahwasanya Allah Maha Kuasa atas segala sesuatu, dan Sesungguhnya Allah ilmu-Nya benar-benar meliputi segala sesuatu. "(ath-Thalaq: 12).

Pendidikan Akhlak adalah pendidikan yang berasaskan AlQur'an dan Hadits Nabi Saw. Hal ini dapat dipahami bahwa pendidikan Islam pada intinya menjalankan semua isi dari dua pedoman tersebut, dua pendoman tersebut merupakan pedoman dalam agamaa Islam. Islam adalah syariat Allah yang diturunkan kepada manusia di muka bumi agar mreka beribadah kepadaNya. Penanaman keyakinak terhadap Tuhan hanya bisa dilakukan melalui proses pendidikan baik di rumah, sekolah maupun lingkungan. Pendidikan Islam merupakan kebutuhan manusia karna sebagai makhluk pedagogis manusia dilahirkan dengan membawa potensi dapat 
dididik dan mendidik sehngga mampu menjadi khalipah di bumi, serta pendukung dan pemegang kebudayaan.

(Abdul Majid dan Dian Andayani, 2005, p.130)

2. Taqwa kepada Allah sesuai kesanggupan

(Berakhlaq dengan bertaqwa kepadaNya).( Harun Yahya, 2004, p.9)

Karena, hakikat manusia itu adalah makhluk Tuhan yang pada darsarnya, manusia membutuhkan Dzat yang Maha kuasa sebagai tempat berlindung. (Rosihon Anwar, 2014, p.91) Semakin tebal ketaqwaan seseorang kepada Allah, semakin tinggi kemampuannya merasakan kehadirat Allah. Allah menginginkan manusia agar bertaqwa dengan sebenarbenarnya. Hal ini merujuk pada Firman Allah Dalam Qur'an Surat at-Taghaabun: 16).(Harun Yahya, 2004, p.9)

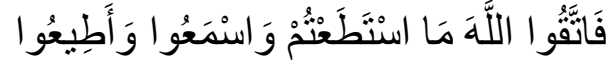

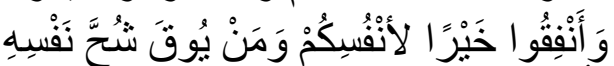

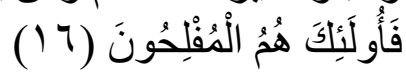
Artinya:"16. Maka bertakwalah kamu kepada Allah menurut kesanggupanmu dan dengarlah serta taatlah dan nafkahkanlah nafkah yang baik untuk dirimu dan Barangsiapa yang dipelihara dari kekikiran dirinya, Maka mereka Itulah orang-orang yang beruntung".(Tagahaabun:16).

3. Takdir. (Harun Yahya, 2004, p.9)

Tidak ada sesuatu pun di alam ini yang terjadi secara kebetulan, sebagaimana tertuang dalam al-Qur'an Surat ar-Ra'd: 2) dan dalam ayat lain dikatakan “...dan tidak sehelai daun pun yang gugur melainkan Dia mengetahuinya (pula)..." (alAn'aam: 59) Dialah Allah yang menciptakan dan mengatur semua peristiwa, bagaimana mereka berawal dan berakhir. Dia pulalah yang menentukan setiap gerakan bintang-bintang di jagat raya, kondisi setiap yang hidup dibumi, cara hidup seseorang, apa yang akan dikatakannya, apa yang akan dihadapinya, sebagaimana dijelaskan dalam al Qur'an.

مَا أَصَابَ مِنْ مُصِيَبَة فِي الأرْضِ وَلا فِي

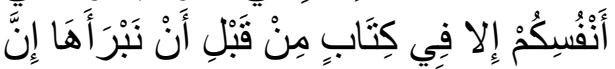

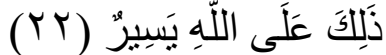

Artinya: "Tiada suatu bencanapun yang menimpa di bumi dan (tidak pula) pada dirimu sendiri melainkan telah tertulis dalam kitab (Lauhul Mahfuzh) sebelum Kami menciptakannya. Sesungguhnya yang demikian itu adalah mudah bagi Allah.(QS alQamar:49).

Beriman kepada takdir Allah merupakan salah satu rukun dari rukun Iman. Sebagaimana telah dijelaskan oleh Rasulullah SAW, dalam Hadis Jibril dengan sabdanya "Hendaklah Engkau beriman kepada takdir yang baik dan buruk". (Rosihon Anwar, 2014, p.191) Yang dimaksud dengan beriman kepada qadha dan qadar (Takdir) ialah bahwa setiap manusia wajib mempunyai itikad atau keyakinan yang sungguhsungguh bahwa sanya segala 
sesuatu yang dilakukan oleh seluruh makhluk, baik yang sengaja, seperti makan, minum, duduk, berdiri atau pun yangtidak disengaja seperti jatuh, terpeleset, pingsan, dsb telah ditetapkan oleh Allah SWT. Sejak zaman azali dan sudah ditulis di dalam Lauhul Mahfudz (papan tuis yang terplihara).Jadi semua yang terjadi di dunia ini telah diketahui oleh Allah SWT., jauh sebelum hal itu trejadi di bumi. (Rosihon Anwar, 2014, p.191)

4. Iman kepada Allah (Berakhlaq dengan berIman/Mempercayai Allah). (Harun Yahya, 2004, p.11)

Yang berpusat pada pengakuan terhadap eksistensi dan kemaha Esaan-Nya.Keimanaan kepada Allah ini merupakan keimanan yang menduduki peringkat pertama. Dari situ dengan sendirinya akan lahir keimanan pokok-pokok (rukun) iman yang lain. Sepanjang seorang itu beriman kepada Allah, niscaya ia akan beriman kepada para malaikat, kitab suci, para rasul, hari kiamat, ketentuan baik dan buruk sebab rukun iman yang disebutkan belakangan merupakan cabang dari keimanan kepada Allah ini.(Afif Muhammad, 1996, p.26) Allah adalah pembuat keputusan, setiap kejadian merupakan anugrah bagi makhluk-Nya, segala sesuatu telah direncanakan untuk kebaikan agama dan untuk kehidupan di akherat kelak Untuk alasan tersebut, manusia harus selalu mempercayai Allah bersikap sebagaimana yang Allah
Inginkan: Memenuhi tanggung jawabnya kemudian berserah diri kepada Allah dengan hasilnya. Hal ini terungkap dalam Qur'an surat ath-Thalaaq: 2-3). (Harun Yahya, 2004, p.11)

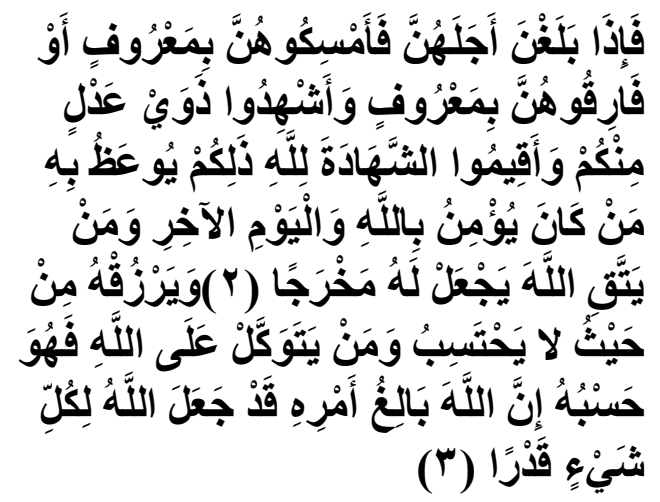

Artinya: "2. Apabila mereka telah mendekati akhir iddahnya, Maka rujukilah mereka dengan baik atau lepaskanlah mereka dengan baik dan persaksikanlah dengan dua orang saksi yang adil di antara kamu dan hendaklah kamu tegakkan kesaksian itu karena Allah. Demikianlah diberi pengajaran dengan itu orang yang beriman kepada Allah dan hari akhirat. Barangsiapa bertakwa kepada Allah niscaya Dia akan Mengadakan baginya jalan keluar.3. Dan memberinya rezki dari arah yang tiada disangka-sangkanya. dan Barangsiapa yang bertawakkal kepada Allah niscaya Allah akan mencukupkan (keperluan)nya. Sesungguhnya Allah melaksanakan urusan yang (dikehendaki)Nya. Sesungguhnya Allah telah Mengadakan ketentuan bagi tiap-tiap sesuatu.(QS ath-Thalaaq:2-3) 
5. Berdo'a (Berakhlaq dengan Meminta atau berdo'a kepada Allah).

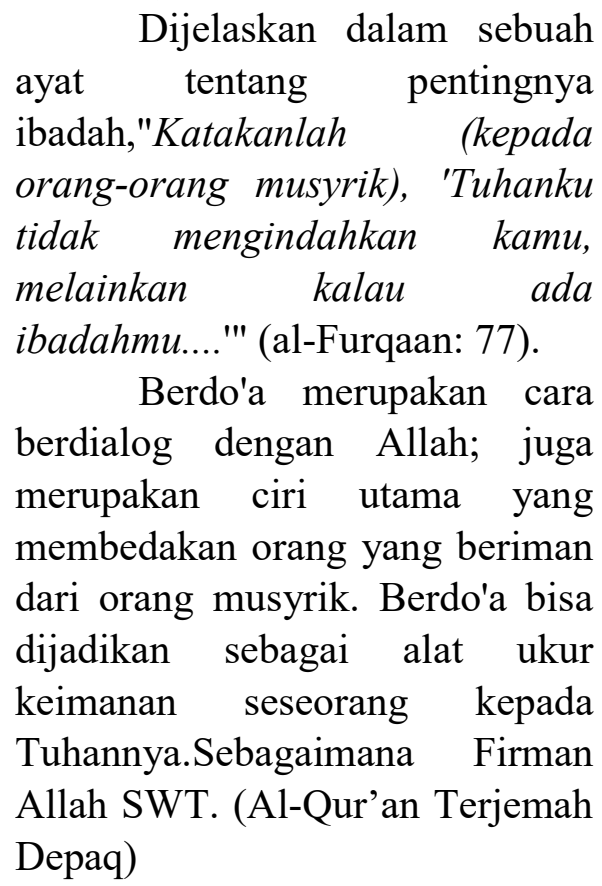

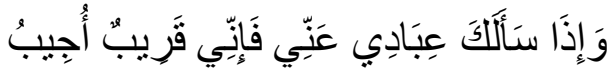

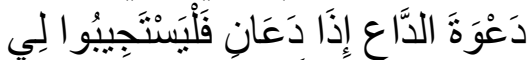

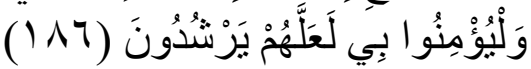
Artinya: "Dan apabila hambahamba-Ku bertanya kepadamu tentang Aku, maka (jawablah), bahwasanya Aku adalah dekat. Aku mengabulkan permohonan orang yang berdo'a apabila ia memohon kepada-Ku, maka hendaklah mereka itu memenuhi (segala perintah)Ku dan hendaklah mereka beriman kepada-Ku, agar mereka selalu berada dalam kebenaran." (alBaqarah: 186)

Akan tetapi, haruslah dipahami bahwa Allah tidak harus mengabulkan semua yang diinginkan dari-Nya. Bagi orangorang yang jahil, "Dan manusia mendo'a untuk kejahatan sebagaimana ia mendo`a untuk kebaikan. Dan adalah manusia bersifat tergesa-gesa." (al-Israa`: 11) Dengan demikian, Allah menjawab semua do'a kita, namun terkadang mengabulkan, terkadang tidak bila ternyata akan menimbulkan "keburukan" yang nyata.Cara berdo'a juga dijelaskan dalam Al-Qur'an: dengan kerendahan hati dan suara yang lembut, keihlasan, dalam hati kita berharap, namun takut pada Allah, serta dengan kesungguhan. (AlQur'an Terjemah Depaq)

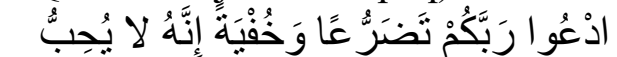

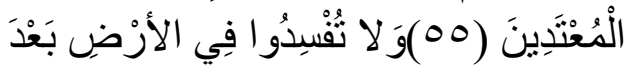

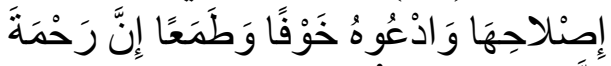

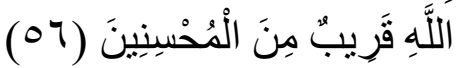
Artinya: "Berdo'alah kepada Tuhanmu dengan berendah diri dan suara yang lembut... berdo'alah kepada-Nya dengan rasa takut (tidak akan diterima) dan harapan (akan dikabulkan). Sesungguhnya, rahmat Allah amat dekat kepada orang-orang yang berbuat baik." (al-A'raaf: 55-56). Dalam ayat lain dikatakan, "Hanya milik Allah asma`ul husna, maka bermohonlah kepada-Nya dengan menyebut asma`ul husna itu...." (al-A'raaf: 180)

Sebenarnya, do'a-do'a kita merupakan pengakuan atas kelemahan kita dengan menunjukkan rasa terima kasih kepada Allah. Tanpa berdo'a berarti menunjukkan kesombongan dan pembangkangan kepada Allah. Allah menyatakan, Dalam Qur'an Surat al-Mu'min: 60. 


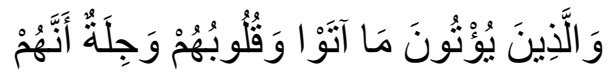

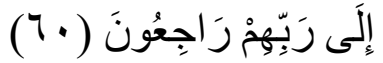
Artinya: "Dan Tuhanmu berfirman, 'Berdo'alah kepada$K u$, niscaya akan Kuperkenankan bagimu. Sesungguhnya, orangorang yang menyombongkan diri dari menyembah-Ku akan masuk neraka Jahannam dalam keadaan hina dina."' (al-Mu'min: 60)

Berdo'a pada Allah adalah ibadah dan juga rahmat yang besar. Tindak permohonan yang mudah ini merupakan kunci untuk mencapai tujuan, baik dunia maupun akhirat.(Harun Yahya, 2004, p.29)

6. Penyesalan dan Memohon Ampun. (Harun Yahya, 2004, p.30)

Dua sifat Allah yang paling sering diulang dalam AlQur'an adalah "Maha Pengasih" dan "Maha Penyayang". Allah benar-benar menyayangi hambahamba-Nya dan tidak menghukum mereka secara langsung atas dosadosa mereka, Dalam Qur'an Surat an-Nahl: $\quad 61 . \quad$ Allah memberitahukan kepada manusia bahwa:

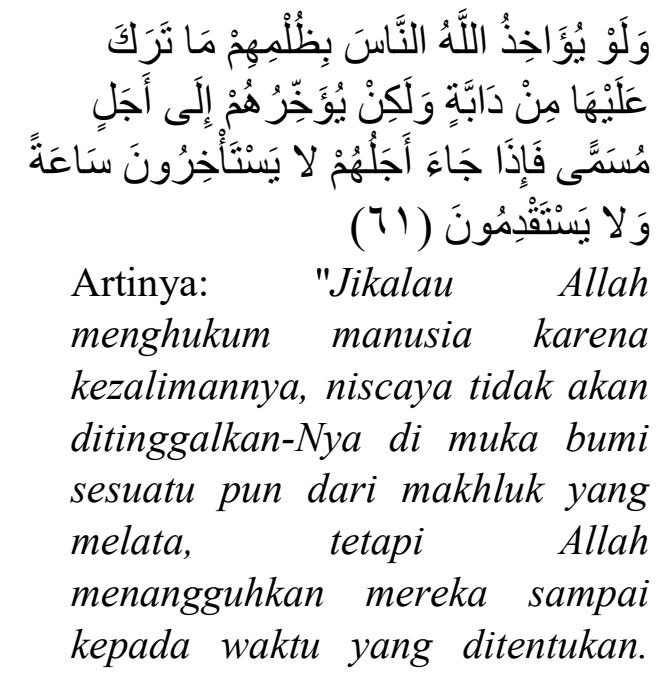

Maka apabila telah tiba waktu (yang ditentukan) bagi mereka, tidaklah mereka dapat mengundurkannya barang sesaat pun dan tidak (pula) mendahulukannya." (an-Nahl: 61) Dengan menangguhkan hukuman, Dia memberi waktu kepada orang yang berbuat salah untuk memohon ampun dan bertobat. Tidak peduli betapa besar dosa yang ia lakukan, ia selalu mendapat kesempatan untuk dimaafkan jika bertobat dan berbuat kebaikan, Hal ini termaktub dalam al-Qur'an Qur'an Surat al-An'am ayat : 54 . (Al-Quran Terjemah Depaq)

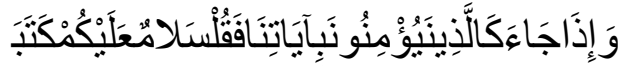

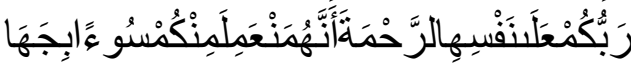

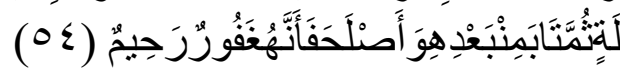
Artinya: "Apabila orang-orang yang beriman kepada ayat-ayat Kami itu datang kepadamu, maka katakanlah, 'Salaamun 'alaikum. Tuhanmu telah menetapkan atas diri-Nya kasih sayang, (yaitu) bahwasanya barangsiapa yang berbuat kejahatan di antara kamu lantaran kejahilan, kemudian ia bertobat setelah mengerjakannya dan mengadakan perbaikan, maka sesungguhnya Allah Maha Pengampun lagi Maha Penyayang."' (al-An'aam: 54)

Tobat juga berarti permohonan dukungan dan kekuatan dari Allah untuk membantu orang yang bersalah agar tidak mengulangi perbuatan salah yang sama. Bentuk Tobat yang diterima Allah adalah yang diikuti dengan perbuatan- 
perbuatan baik, Allah Berfirman dalam Qur'an Surat al-Furqaan: 71. Bahwa: (Al-Qur'an Terjemah Depaq)

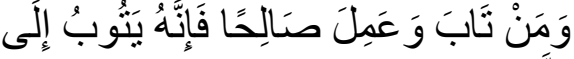

$$
\begin{aligned}
& \text { اللَّهِ مَتَابًَا (V) (V) }
\end{aligned}
$$

Artinya: "Dan orang yang bertobat dan mengerjakan amal saleh, maka sesungguhnya dia bertobat kepada Allah dengan tobat yang sebenar-benarnya." (al-Furqaan: 71)

Terkadang seseorang bisa saja melakukan dosa yang sama karena bujukan nafsunya, bahkan setelah bertobat. Akan tetapi, hal ini bukanlah alasan baginya untuk tidak bertobat. Dia bisa bertobat karena kesalahan-kesalahan sepanjang hidupnya. Harus diingat pula bahwa tobat seseorang tidak akan diterima ketika kematian telah datang menjemput dan ia mulai melihat nasibnya di hari kemudian. Firman Allah SWT. (Al-Qur'an Terjemah Depaq)

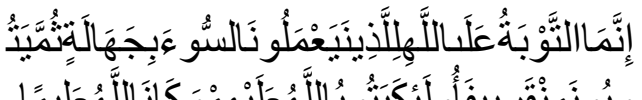

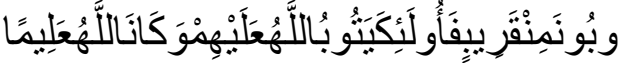

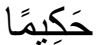

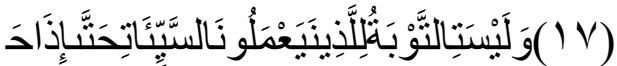

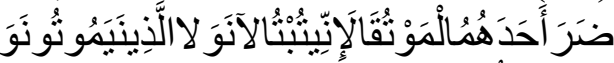

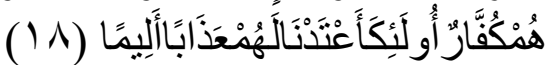
Artinya:"Sesungguhnya, tobat di sisi Allah hanyalah tobat bagi orang-orang yang mengerjakan kejahatan lantaran kejahilan, yang kemudian mereka bertobat dengan segera, maka mereka itulah yang diterima Allah tobatnya; dan Allah Maha
Mengetahui lagi Mahabijaksana." (an-Nisaa': 17)

"Dan tidaklah tobat itu diterima Allah dari orang-orang yang mengerjakan kejahatan (yang) hingga apabila datang ajal kepada seseorang di antara mereka, (barulah) ia mengatakan, 'Sesungguhnya, saya bertobat sekarang.' Dan tidak (pula diterima tobat) orang-orang yang mati sedang mereka di dalam kekafiran. Bagi orang-orang itu telah Kami sediakan siksa yang pedih." (an-Nisaa`: 18)

Ayat yang lain menyeru orangorang beriman kepada keselamatan, "... Dan bertobatlah kamu sekalian kepada Allah, hai orang-orang beriman supaya kamu beruntung." (an-Nuur: 31)

7. Sabar. (Harun Yahya, 2004, p.32)

Manusia diciptakan dengan disertai sifat tidak sabar dan karenanya ia banyak berbuat kesalahan. Akan tetapi, agama meminta setiap orang agar bersabar karena Allah. Orang beriman, terutama, harus sabar menunggu keselamatan yang besar yang Allah janjikan. Inilah perintah di dalam Al-Qur`an, "Dan untuk (memenuhi perintah) Tuhanmu, bersabarlah." (alMuddatstsir: 7). Sabar merupakan salah satu sifat penting untuk mencapai ridha Allah; itulah kebaikan yang harus diusahakan agar lebih dekat kepada Allah. Hal ini sesuai dengan Firman Allah, Bahwa: (Al-Qur'an Terjemah Depaq) 


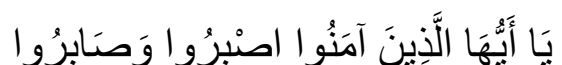

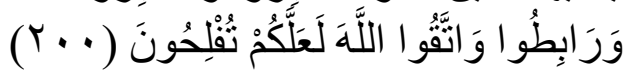

Artinya: "Hai orang-orang yang beriman, bersabarlah kamu dan kuatkanlah kesabaranmu dan tetaplah bersiap siaga (di perbatasan negerimu) dan bertaqwalah kepada Allah supaya kamu beruntung." (Ali Imran: 200)

Dalam masyarakat jahiliah, arti sabar bercampur dengan ketahanan diri. Akan tetapi, ketahanan diri memiliki makna yang berbeda, yaitu menahan sakit atau kesusahan. Makna sabar yang sebenarnya dijelaskan dalam Al-Qur`an. Perbedaan ini hanya dipahami oleh orang-orang yang benarbenar beriman. Ketekunan orangorang beriman bertujuan untuk mencapai ridha Allah. Dengan demikian, sabar memberikan penerangan bagi orang beriman, sedangkan "ketahanan diri" hanya memberikan kejengkelan dan kesusahan bagi orang-orang yang tidak beriman. Al-Qur'an menyatakan hal ini, "Jadikanlah sabar dan shalat sebagai penolongmu. Dan sesungguhnya yang demikian itu sungguh berat, kecuali bagi orang-orang yang khusyuk." (al-Baqarah: 45)

Ayat lain dari surah yang sama menekankan bahwa kegembiraan diberikan kepada orang-orang yang bersabar dalam menghadapi rintangan atau kesusahan. Firman Allah SWT. (Al-Qur'an Terjemah Depaq)

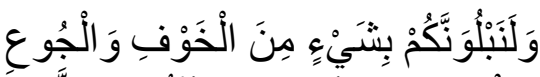

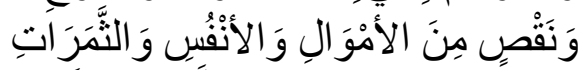

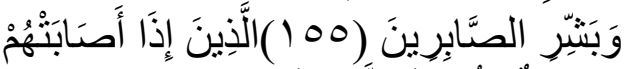

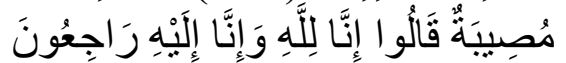

(107)

Artinya: "Dan sungguh akan Kami berikan cobaan kepadamu, dengan sedikit ketakutan, kelaparan, kekurangan harta, jiwa dan buah-buahan. Dan berikanlah berita gembira kepada orang-orang yang sabar, (yaitu) orang-orang yang apabila ditimpa musibah, mereka mengucapkan, 'Innaa lillaahi wa innaa ilaihi raajiuun."' (alBaqarah: 155-156)

Sabar merupakan sifat mulia yang dapat meningkatkan kekuatan orang-orang beriman. Allah menyatakan pada ayat berikut, betapa kekuatan sabar ini bisa mengalahkan sesuatu.

الآنَ خَفَّفَ اللَّهُ عَنْكُمْ وَعَلِمَ أَنَّ فِيكُْْ ضَعَعْفًا

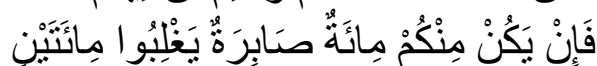

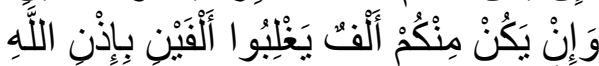

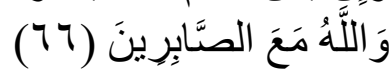

Artinya: "Sekarang, Allah telah meringankan kepadamu dan Dia telah mengetahui bahwa padamu ada kelemahan. Maka jika ada di antaramu seratus orang yang sabar, niscaya mereka dapat mengalahkan dua ratus orang; dan jika di antaramu ada seribu orang (yang sabar), niscaya mereka dapat mengalahkan dua ribu orang dengan seizin Allah. Dan Allah beserta orang-orang yang sabar." (al-Anfaal: 66)

Sabar, sekali lagi, merupakan sifat yang tergolong 
positif yang diterangkan dalam Al-Qur'an. Seseorang bisa saja rendah hati, sederhana, baik budi, taat atau patuh; namun semua kebaikan ini hanya akan berharga ketika kita menggabungkannya dengan kesabaran. Kesabaranlah yang diperlihatkan dalam berdo'a dan merupakan sifat orang beriman, yang membuat do'a-do'a kita dapat diterima.(Harun Yahya, 2004, p.34)

Sabar meliputi seluruh kehidupan orang beriman, yang patuh pada ketentuan, "Sabarlah untuk tuhanmu." Akhirnya, Allah mengambil jiwa mereka dan memberi mereka penghargaan dengan surga-Nya. Malaikat yang berjaga di pintu-pintu menyebut orang yang benar dengan perkataan.

8. Menilai Segala Sesuatu Dengan Cara Pandang AlQur'an.(Harun Yahya, 2004, p.40)

Orang-orang beriman bertujuan menjadi hamba Allah yang sebenar-benarnya. Manusia tidak diciptakan untuk memenuhi keserakahan atau menuruti hawa nafsunya; satu-satunya alasan penciptaan manusia adalah untuk menyembah Allah. Jalan untuk mencapai tujuan ini adalah dengan menjadikan Al-Qur'an sebagi panduan hidup kita. Kita harus mencurahkan segala perhatian untuk mengamalkan setiap ketentuan Al-Qur`an. Kita harus mengamalkan setiap keputusan Al-Qur`an sebanyak mungkin.

Kita tahu dari Al-Qur'an bahwa kewajiban orang-orang beriman tidak hanya berhenti pada ayat-ayat tertentu, seperti shalat, puasa, atau berhaji, tetapi juga penerjemahan dari ibadah itu sendiri. Sebagai contoh, dalam sebuah ayat, orang yang beriman disuruh, "Serulah (manusia) kepada jalan Tuhanmu dengan hikmah dan pelajaran yang baik dan bantahlah mereka dengan cara yang baik...." (an-Nahl: 125). Orang-orang beriman memahami "hikmah dan pelajaran yang baik" dengan mengamalkan ajaran AlQur'an serta ilmu pengetahuan mereka.

Masih banyak kewajiban lain yang membutuhkan ilmu pengetahuan. Contohnya, AlQur`an menjelaskan bermacammacam kaum dan menginformasikan kepada kita cara memperlakukan kaum tersebut. Apa yang harus diucapkan kepada kaum tersebut, sebagian besar ayat Al-Qur'an dimulai dengan, "Katakanlah...."

Dengan jelas, ayat-ayat Al-Qur'an memberikan gambaran kepada orang beriman tentang cara bersikap. Akan tetapi, jika perintah-perintah ini diaplikasikan dalam kehidupan sehari-hari, harus ditafsirkan dengan benar. Pada saat tersebut, ilmu pengetahuan orang-orang beriman sangat membantu. (Harun Yahya, 2004, p.41)

Al-Qur`an menjelaskan berbagai jenis kaum, seperti kaum muslimin, Kristen, Yahudi, orang munafik, dan penyembah berhala. Kita harus mempelajari ayat-ayat tersebut dengan baik, karena yang seharusnya dilakukan adalah 
mengenali kaum-kaum ini dalam masyarakat kita kemudian bersikap kepada mereka sesuai dengan perintah-perintah dalam Al-Qur’an. Dengan demikian, kita akan menjadi apa yang Al-Qur'an inginkan. Lagi pula, orang beriman harus mengenali semua orang di sekitarnya, yang tidak diragukan lagi memiliki satu atau lebih sifat-sifat kaum yang dijelaskan Al-Qur'an. Orangorang tersebut membentuk masyarakat yang dijelaskan AlQur'an dan tiada satu pun yang diciptakan sia-sia,

\section{وَمَا خَلَقْنَا السَََّاءَ وَالأزَْْ وَمَا بَيْنَهُهَا}

$$
\text { لا عَبِينَ (1 } 1 \text { (1) }
$$

Artinya: "Dan tidaklah Kami ciptakan langit dan bumi dan segala yang ada di antara keduanya dengan bermain-main." (al-Anbiyaa`: 16)

Walaupun demikian, tidak hanya orang-orang di sekitar kita yang dijelaskan dalam Al-Qur`an. Sebenarnya, segala sesuatu yang kita lihat dan semua yang terjadi merupakan pencerminan dari yang tertulis dalam Al-Qur`an,

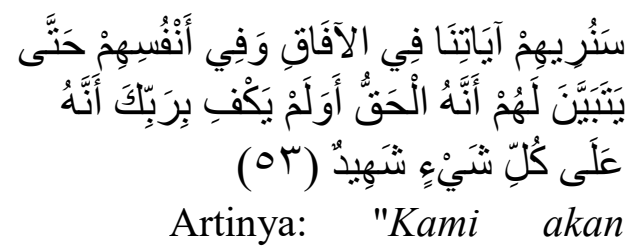
memperlihatkan kepada mereka tanda-tanda (kekuasaan) Kami di segenap ufuk dan pada diri mereka sendiri, sehingga jelaslah bagi mereka bahwa Al-Qur'an itu adalah benar. Dan apakah Tuhanmu tidak cukup (bagi kamu) bahwa sesungguhnya Dia menyaksikan segala sesuatu?" (Fushshilat: 53)

Seluruh alam memiliki tanda-tanda keberadaan Allah, seperti halnya sebuah lukisan yang menghadirkan pelukisnya kepada yang melihatnya. Selukbeluk lukisan ini menunjukkan sapuan kuas yang jelas; seluruh alam dan seluk-beluk alam ini ada untuk menghadirkan Allah, Pencipta segala sesuatu. Semakin disadarinya kenyataan ini oleh orang beriman, mereka akan semakin mengenali Allah dan bersungguh-sungguh mematuhi semua perintah-Nya. Ketika seseorang memahami kehidupan dengan seluk-beluknya, yang merupakan "tanda" yang dijelaskan dalam Al-Qur`an, orang tersebut akan menghubungkan segala sesuatu dalam "kehidupan sehari-harinya" dengan nilai-nilai Al-Qur’an. (Harun Yahya, 2004, p.42)

Segala sesuatu yang mengambil tempat dalam takdir Allah, telah ditentukan dan karenanya memiliki tujuan. Yang harus dilakukan oleh orang beriman adalah menafsirkan setiap kejadian dalam cahaya AlQur'an, yaitu bertindak sesuai dengan jalan yang telah dijelaskan Al-Qur`an. Sebagai contoh, ketika berhadapan dengan sesuatu yang sia-sia dan bersifat kemalasan, orang beriman harus mengabaikannya, karena diciptakannya sesuatu yang sia-sia itu agar orang beriman tidak mengindahkannya. Orang beriman harus menerjemahkan segala sesuatu menurut cara pandang Al- 
Qur`an. Dengan demikian, mereka harus membangun budaya dan karakter mereka dalam bingkai Al-Qur`an, sebagaimana perintah Allah untuk mencapai kondisi ini, yaitu mereka harus meninggalkan semua yang mereka peroleh dari masyarakat dan kebodohan mereka yang lampau. Mereka harus memutuskan apa yang seharusnya dilakukan pada setiap situasi dengan bergantung pada penafsiran dan logika Al-Qur'an, karena ayat-ayat Allah menunjukkan kepada mereka cara mengatasi setiap situasi. Hal ini sebagaimana yang dikatakan dalam Al-Qur'an bahwa telah diturunkan kepada kita sebuah kitab "untuk menjelaskan segala sesuatu" (an-Nahl: 89).

9. Bersyukur Kepada Allah. (Berakhlaq dengan Bersyukur kepada Allah SWT). (Harun Yahya, 2004, p.52)

Allah menciptakan segala sesuatu dengan tujuan tertentu, seperti anugerah-Nya. Setiap anugerah hidup, keimanan, makanan, kesehatan, sepasang mata dan telinga kita merupakan anugerah kepada manusia agar bersyukur kepada-Nya.

Ketika kita meninggalkan ketidak acuhan dan kebodohan serta berfikir dan merenung, kita pasti menyadari bahwa segala sesuatu di sekitar kita merupakan anugerah dari pencipta kita yaitu Allah. Semua makanan yang kita nikmati, udara untuk kita bernafas, keindahan disekitar kita mata kitalah yang membuat semua ini. Semuanya merupakan anugerah dari Allah. Sedemikian banyaknya anugerah ini sehingga digambarkan dalam al-Qur'an. (Harun Yahya, 2004, p.52)

Allah berfirman dalam surat an-Nahl: 18. (Al-Quran terjemah Depaq)

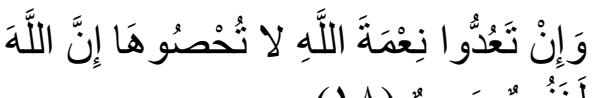

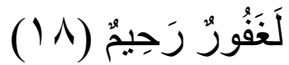

Artinya: "Dan jika kamu menghitung-hitung nikmat Allah, niscaya kamu tak dapat menentukan jumlahnya. Sesungguhnya Allah benar-benar Maha Pengampun lagi Maha Penyayang"(an-Nahl: 18).

Tanpa diragukan lagi, semua anugerah ini diberikan dengan sebuah alasan. Tidak ada sesuatu pun diciptakan bagi kita untuk digunakan sebagaimana kehendak kita sendiri. Sebaliknya, alasan bagi semua kemurahan ini apapun bentuknya adalah perintah kepada manusia supaya menuju ketentuan Allah. Hal ini karena segala sesuatu yang diberikan Allah mengharuskan kita bersyukur sebagai balasannya. Allah lah yang memberikan rahmat. Karena itu, kita harus menunjukkan keikhlasan bersyukur hanya kepada-Nya.

Rasa syukur merupakan ibadah dan juga cara untuk melindungi kita dari penyimpangan. Tidak bersyukur berarti melangkah menuju kerusakan dan kejahatan, melupakan kelemahan-kelemahan dan menjadi takabur ketika mereka semakin kaya dan berkuasa. Menunjukkan rasa syukur pada Allah berarti 
melindungi dari kerusakan. Berarti mereka mengetahui bahwasannya mereka bertanggung jawab menggunakan semua rahmat ini di jalan Allah dan seperti kehendak-Nya. Itulah rasa syukur kepada Allah yang didasari kerendahan hati dan kedewasaan para Rasul. Seperti Nabi Daud as. Atau Nabi Sulaiman as yang kepadanya diberikan harta, kedudukan, dan ketundukan. Sebenarnya peristiwa Qarun yang menjadi ingkar disebabkan harta adalah karena ia tidak bersyukur kepada Allah SWT. (Harun Yahya, 2004, p.53)

Jika orang beriman tidak menjadi takabur dan melampaui batas dengan rahmat dan harta yang diberikan kepadanya, Allah akan menambahkan kenikmatan yang telah diberi, seperti firmanNya dalam surat Ibrahim: 7

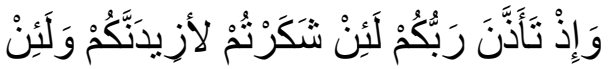

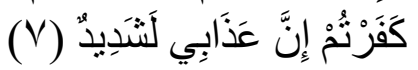

Artinya: "Dan (ingatlah juga), tatkala Tuhanmu memaklumkan; "Sesungguhnya jika kamu bersyukur, pasti Kami akan menambah (nikmat) kepadamu, dan jika kamu mengingkari (nikmat-Ku), Maka Sesungguhnya azab-Ku sangat pedih"(Ibrahim:7).

Bersyukur tidak harus selalu ditunjukkan dengan katakata. Yang justru harus dilakukan adalah menggunakan setiap anugerah di jalan yang disukai Allah. Sebagai tahap awal, tubuh yang dianugerahkan pada kita harus kita gunakan untuk berjuang karena-Nya.

10. Tidak Ada Yang Lebih Dicintai Daripada Allah Dan Rasul-Nya Serta Berjihad Di Jalan-Nya. (Harun Yahya, 2004, p.60)

Satu kewajiban bagi orang beriman adalah menyembah Allah, satu-satunya alasan keberadaan kita adalah menjadi hamba-Nya. Kehidupan yang tidak didasari alasan ini berarti menolak agama Allah dan menyembah selain Allah, yang akibatnya akan membuat seseorang masuk neraka.

Dengan kata lain kehidupan adalah alat unutk orang beriman. Dia harus menghargai setiap saat dalam hidupnya untuk dekat pada Allah dan melaksanakan kehendak-Nya. Orang-orang beriman hidup hanya untuk satu sebab yaitu, menyembah Allah dan karenanya mereka meninggalkan keduniawian. (Harun Yahya, 2004, p.61) Allah menjelaskan hal ini dalam firman-Nya:

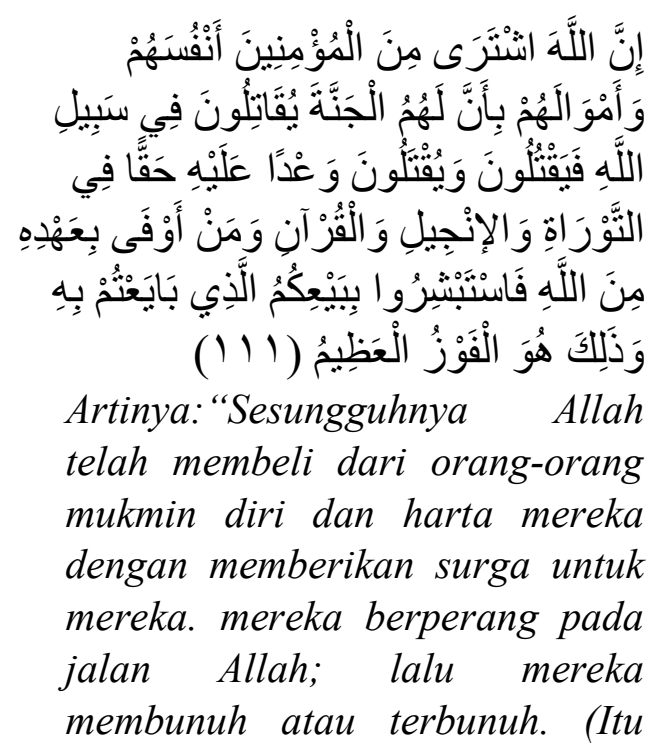


telah menjadi) janji yang benar dari Allah di dalam Taurat, Injil dan Al Quran. dan siapakah yang lebih menepati janjinya (selain) daripada Allah? Maka bergembiralah dengan jual beli yang telah kamu lakukan itu, dan Itulah kemenangan yang besar"(At-Taubat:111).

Orang-orang beriman menjual harta dan jiwanya pada Allah dan tidak ada lagi hak baginya. Seluruh hidupnya dibaktikan di jalan yang Allah perintahkan. Jika Allah mengaruniai mereka mereka akan bersyukur, dan jika mereka diperintah berjihad di jalan-Nya mereka tidak merasa ragu sedikit pun bahwa jika mereka mengetahui mereka sedang menuju kematian.

Orang-orang yang beriman sebenarnya tidak akan lalai pada kepuasan pribadi dan tidak ada sesuatu pun di bumi ini yang dapat mencegahnya dari berjihad di jalan Allah.Keimanan yang sangat kuat pada diri sahabat Nabi membuat mereka tidak pernah menolak pertempuran. Sebaliknya, beberapa di antara mereka ada yang berurai air mata ketika mereka tidak berkesempatan berjihad bersama Nabi. Pada ayat berikut Allah menjelaskan perbedaan antara orang yang ikhlas dan setengah hati: Firman Allah SWT:

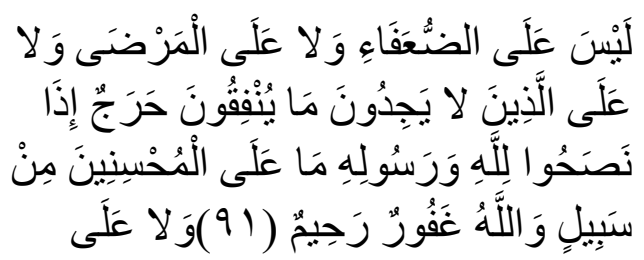

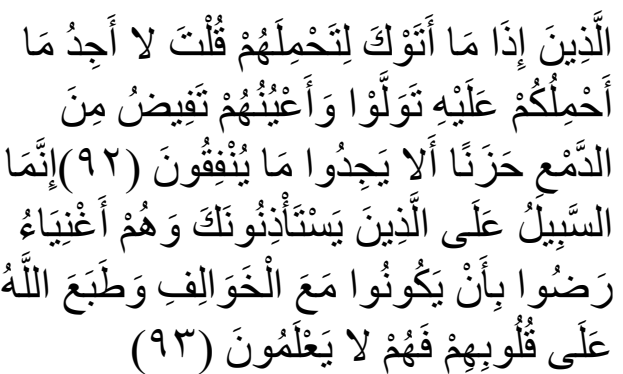

Artinya:91. tiada dosa (lantaran tidak pergi berjihad) atas orangorang yang lemah, orang-orang yang sakit dan atas orang-orang yang tidak memperoleh apa yang akan mereka nafkahkan, apabila mereka Berlaku ikhlas kepada Allah dan Rasul-Nya. tidak ada jalan sedikitpun untuk menyalahkan orang-orang yang berbuat baik. dan Allah Maha Pengampun lagi Maha Penyayang,92. dan tiada (pula) berdosa atas orang-orang yang apabila mereka datang kepadamu, supaya kamu memberi mereka kendaraan, lalu kamu berkata: "Aku tidak memperoleh kendaraan untuk membawamu." lalu mereka kembali, sedang mata mereka bercucuran air mata karena kesedihan, lantaran mereka tidak memperoleh apa yang akan mereka nafkahkan.93. Sesungguhnya jalan (untuk menyalahkan) hanyalah terhadap orang-orang yang meminta izin kepadamu, Padahal mereka itu orang-orang kaya. mereka rela berada bersama orang-orang yang tidak ikut berperang dan Allah telah mengunci mati hati mereka, Maka mereka tidak mengetahui (akibat perbuatan mereka).(At-Taubat:91-93).

11. Tidak Lemah, Bersedih Hati, dan Berputus Asa'(Harun Yahya, 2004, p.63) 
Orang-orang beriman memiliki perjuangan berat dan panjang di jalan Allah. Jalan hidup mereka sering diserang musuh yang jumlahnya sangat banyak dan dengan peralatan yang lebih baik. Akan tetapi, sepanjang mereka berada di jalan Allah mereka dapat mengatasinya.

Salah satu alasan bagi kemenangan mereka, sebagai orang beriman mereka melakukan perjuangan dengan semangat dan kegembiraan yang besar. Inilah yang tidak dapat dilakukan oleh orang-orang yang ingkar karena mereka telah mencintai kehidupan dunia, mereka tidak beriman pada Allah. Mereka takut dan lemah serta mudah menyerah ketika menghadapi kesulitan. Sebaliknya, orang-orang beriman tidak mudah dilemahkan karena mereka tahu bahwa Allah selalu bersama mereka dan mereka berharap menjadi orang yang berhasil. Hal ini diterangkan dalam al-Qur'an: (Al-Qur'an terjemah Depaq) Firman Allah SWT:

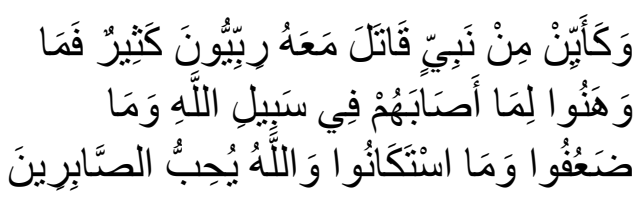

$(1 \leq 7)$

Artinya: "Dan berapa banyaknya Nabi yang berperang bersamasama mereka sejumlah besar dari pengikut (nya) yang bertakwa. mereka tidak menjadi lemah karena bencana yang menimpa mereka di jalan Allah, dan tidak lesu dan tidak (pula) menyerah (kepada musuh). Allah menyukai orang-orang yang sabar.'(Ali Imran: 146).

Orang yang beriman hanya bertanggung jawab kepada dirinya dan Allah serta tidak seharusnya tidak terpengaruh oleh kelemahan yang lain. Kekuatan musuh pun tidak mempengaruhi dan membuatnya takut. Seluruh hidup orang beriman hanyalah untuk Allah.(Harun Yahya, 2004, p.64) Mereka akan terus beribadah demi keridhaan-Nya sampai akhir hayat, pada sebuah ayat dijelaskan:

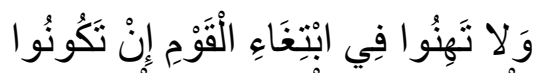

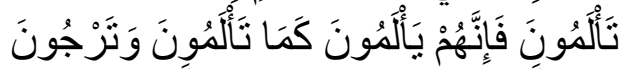

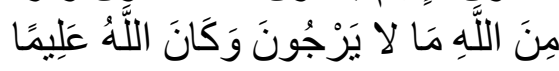

$$
\text { حَكِيمًا (ع (1. (1) }
$$

Artinya: "Janganlah kamu berhati lemah dalam mengejar mereka (musuhmu). jika kamu menderita kesakitan, Maka Sesungguhnya merekapun menderita kesakitan (pula), sebagaimana kamu menderitanya, sedang kamu mengharap dari pada Allah apa yang tidak mereka harapkan. dan adalah Allah Maha mengetahui lagi Maha Bijaksana."(anNissa':104).

12. Merendahkan Diri Ketika Shalat

Shalat sangatlah penting karena hal itu merupakan pernyataan lahiriah seseorang menjadi muslim. Akan tetapi, alqur'an menerangkan jenis shalat yang tidak di sukai yaitu yang tanpa keikhlasan.Hal ini menunjukkan bahwa yang membuat shlat kita menjadi sah bukanlah gerakannya, seperti 
rukuk dan sujud, melainkan tujuan serta apa yang mereka pikirkan pada saat shalat. Beberapa orang melakukan shalat hanya untuk menunjukkan kepada yang lain tentang "kemusliman" mereka, bukan unutk meraih keridhaan Allah. Sesungguhnya mereka melakukan hal yang di luar batas.

Yang membuat shalat kita diterima adalah kesadaran kita bersujud di hadapan Allah hanya untuk menyatakan penyerahan diri kita kepada-Nya. Itulah sebabnya Allah memerintahkan orang-orang beriman. Allah berfirman:

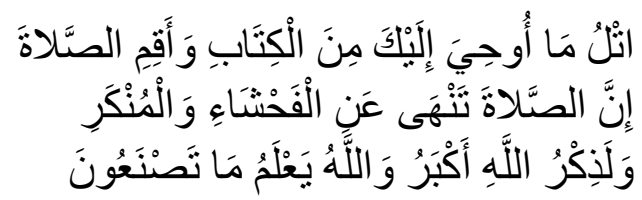

Artinya: "Bacalah apa yang telah diwahyukan kepadamu, Yaitu Al kitab (Al Quran) dan dirikanlah shalat. Sesungguhnya shalat itu mencegah dari (perbuatanperbuatan) keji dan mungkar. dan Sesungguhnya mengingat Allah (shalat) adalah lebih besar (keutamaannya dari ibadat-ibadat yang lain). dan Allah mengetahui apa yang kamu kerjakan."(alAnkabuut: 45)

\section{Bertasbih Memuji Allah} SWT. (Harun Yahya, 2004, p.66)

Semua topik keimanan yang kita bahas hingga kini membutuhkan kepasrahan diri kepada Allah., dalam hidup dan berjuang karena-Nya. Pengabdian ini tidak dapat kita capai kecuali memiliki kedekatan dengan Allah dan jalan untuk khusyuk, melalui "mengingat dan kembali kepadaNya". Orang-orang beriman itu seperti yang diperintahkan dalam al-qur'an. Orang-orang beriman harus bersyukurkepada Allah atas karunia yang diberikan-Nya dan memohon ampunan Allah atas perbuatan dzalim diri mereka. Selanjutnya, mereka harus meminta kepada Allah untuk semua yang mereka butuhkan serta memuji-Nya siang dan malam.

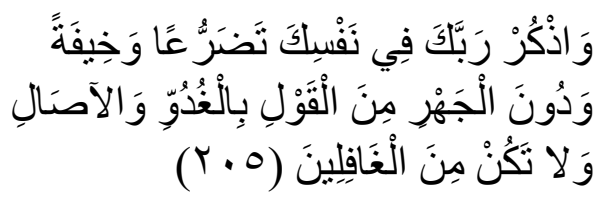

Artinya: "Dan sebutlah (nama) Tuhannmu dalam hatimu dengan merendahkan diri dan rasa takut, dan dengan tidak mengeraskan suara, di waktu pagi dan petang, dan janganlah kamu Termasuk orang-orang yang lalai."(alA'raaf: 205).

Tanpa menghadirkan Allah, semua shalat akan kehilangan nilainya. Jika shalat ini tidak ditujukan untuk mengingat Allah dan mencari ridha-Nya, mereka tidak mendapatkan upah. Ketika al-Qur'an menjelaskan sifat-sifat para Nabi, ditekankan betapa mereka selalu taat kepada Allah.(Harun Yahya, 2004, p.66)

14. Mengingat Allah dalam Setiap Kesulitan. (Harun Yahya, 2004, p.67)

Tujuan hidup orang-orang beriman adalah beribadah kepada Allah. Salah satu cara beribadah adalah menyampaikan ajaran allah dimanapun dan berjuang melawan 
pasukan iblis. Perjuangan ini biasanya sangat berat dan keras karena setiap saat " pasukan iblis " mempunyai peralatan yang lebih baik.

Orang-orang beriman tidak terpengaruh oleh hal ini karena mereka menyadari adanya sebab akibat di dunia. Realita ini mengabarkan bahwa kemenangan tidak berhubungan dengan jumlah yang banyak atau kekuatn yang dahsyat, tetapi atas perintah dan kehendak Allah/ ajaran agama yang benar memberikan penghargaannya berupa kemenangan iman " berapa banyak terjadi golongan yang sedikit dapat mengalahkan golongan yang banyak dengan izin Allah dan Allah beserta orang-orang yang sabar." Keimanan yang murnilah yang menunjukkan kemenangan. Kebenaran yang pelik ini yang tidak dipahami orang-orang yang ingkar, dijelaskan dalam ayat:

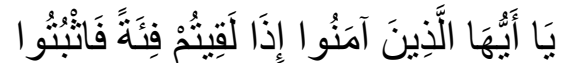

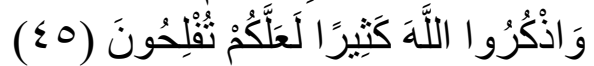
Artinya: 'Hai orang-orang yang beriman. apabila kamu memerangi pasukan (musuh), Maka berteguh hatilah kamu dan sebutlah (nama) Allah sebanyakbanyaknya[620] agar kamu beruntung. "al-Anfaal: 45).

15. Membaca Wahyu Allah SWT. (Harun Yahya, 2004, p.68)

Karena al-Qur'an begitu ajaib dan sangat kompleks yang berisi tentang petunuk bagi manusia di muka bumi, maka perlu kiranya seseorang untuk membaca al-Qur'an. Dalam sejarahnya Nabi menerima wahyu di Gua Hira adalah perintah untuk membaca, melalui diturunkannya surat al-Alaq(Iqro'). Hal ini menunjukkan bahwa al-Qur'an merupakan jendela kehidupan dunia dan akhirat.Memuat beragam dimensi ruang dan waktu (dulu, sekarang dan esok).Selain itu al-Qur'an juga mengandung banyak mutiara hikmah yang sangat berharga bagi kehidupan manusia.(Ferry Taufiq, 2015, p.59)

Sesungguhnya orangorang beriman pada siang hari mempunyai urusan yang banyak. tentu saja kesibukan-ksibukan itu untuk kepentingan agama walaupun kesibukan tersebut membuat orang beriman terlibat dengan masyarakat yang mementingkan dunia. Di tengahtengah urusan dunia pun orangorang beriman menjaga keimanan kepada Allah dan tidak pernah kehilangan pandangan spiritual. Firman Allah:

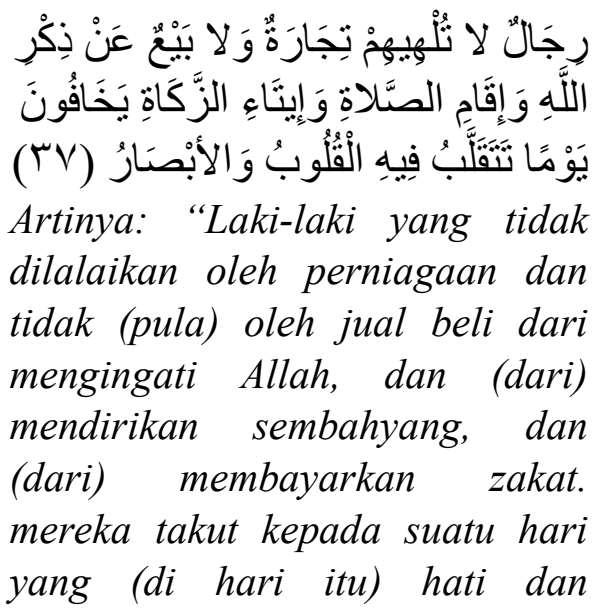


penglihatan

menjadi

goncang. "(an-Nuur: 37$)$.

Hal terpenting dalam kajian ini adalahmenjaga hubungan dengan Allah. Selama orang-orang beriman menjaga alqur'an dalam hatinya mereka dapat mengamalkan ajaran alqur'an dalam kehidupan seharihari selanjutnya akan merasa lebih dekat kepada Allah.

16. Berlindung kepada Allah dari Godaan Setan Ketika Membaca al-Qur'an. (Harun Yahya, 2004, p.77)

Al-Qur'an adalah wahyu Allah yang diturunkan untuk mengingatkan manusia. Ketika alQur'an membantu meningkatkan keimanan orang-orang beriman, pada saat yang sama al-Qur'an mengungkapkan penolakan orangorang yang ingkar. Firman Allah SWT: (Al-Qur'an Terjemah Depaq)

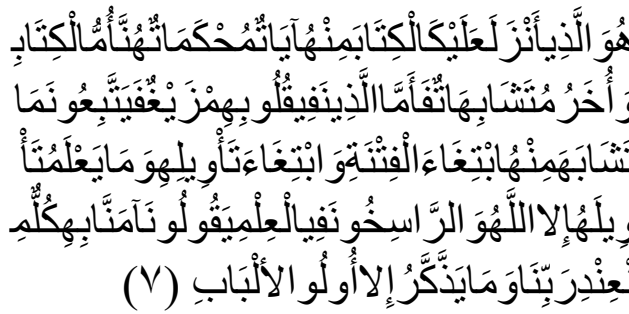
Artinya:"Dialah yang menurunkan Al-Kitab (Al-Qur'an) kepada kamu. Di antara (isi)nya ada ayat-ayat yang muhkamaat itulah pokok-pokok isi Al-Qur'an dan yang lain (ayat-ayat) mutasyaabihaat. Adapun orangorang yang dalam hatinya condong kepada kesesatan, maka mereka mengikuti sebagian ayatayat yang mutasyaabihaat untuk menimbulkan fitnah dan untuk mencari-cari takwilnya, padahal tidak ada yang mengetahui takwilnya melainkan Allah. Dan orang-orang yang mendalam ilmunya berkata, 'Kami beriman kepada ayat-ayat yang mutasyaabihaat, semuanya itu dari sisi Tuhan kami.' Dan tidak dapat mengambil pelajaran (darinya) melainkan orang-orang yang berakal." (Ali Imran: 7)

Hal itu berarti dalam beberapa ayat al-Qur'an terdapat ungkapan tentang penyimpangan "orang-orang yang hatinya condong kepada kesesatan" dan juga peningkatan keimanan dan kepasrahan kaum mukminin. Haruslah dicatat bahwa tidak ada seorang pun yang dapat menjamin bahwa dirinya akan dapat terus memelihara keimanannya. Kaum mukminin bisa kehilangan alQur'an dalam hatinya akibat godaan setan. Biasanya, mereka tidak dapat menangkap hikmah alQur'an sewaktu membacanya ketika berada di bawah pengaruh setan. Itulah sebabnya mengapa Allah memerintahkan orang beriman agar berlindung kepadaNya dari pengaruh setan sebelum membaca al-Qur'an, "Apabila kamu membaca al-Qur'an, hendaklah kamu meminta perlindungan kepada Allah dari setan yang terkutuk." (an-Nahl: 98)

Perintah ini sangat penting karena mengingatkan orang beriman akan kehadiran dan aktivitas setan yang tiada henti. Dalam bekerja, setan menunggu orang-orang yang berada di jalan yang lurus serta mengganggu mereka "dari depan dan belakang, 
dari kanan dan kiri". Strategi iblis tersebut dijelaskan dalam beberapa ayat Al-Qur'an. Keselamatan dari tipu daya iblis dapat diraih hanya melalui alQur'an, yang memperingatkan kita agar melawan trik-trik iblis dan meminta kita agar menghindari mereka. Jalan keluarnya adalah dengan menerima al-Qur`an sebagai satusatunya panduan dan membacanya setelah berlindung kepada Allah dari godaan setan yang terkutuk.

17. Rendah Hati. (Harun Yahya, 2004, p.76)

Manusia yang dapat menahan nafsu akan menjadi orang yang penuh perhatian terhadap sesama. Al-Qur’an memberitakan jenis pengorbanan antara orang-orang Mekah yang hijrah bersama Rasulullah saw. (Muhajirin) dan orang-orang Madinah yang menolong mereka (Anshar),Firman Allah SWT: (AlQur'an Terjemah Depaq)

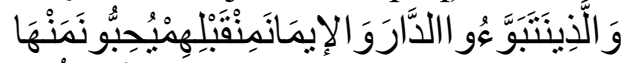

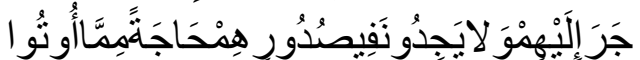

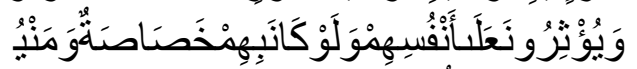

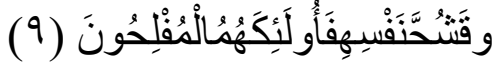

Artinya:"Dan orang-orang yang telah menempati kota Madinah dan telah beriman (Anshar) sebelum (kedatangan) mereka (Muhajirin), mereka mencintai orang yang berhijrah kepada mereka. Dan mereka tiada menaruh keinginan dalam hati mereka terhadap apa-apa yang diberikan kepada mereka (orang Muhajirin); dan mereka mengutamakan (orang-orang
Muhajirin), atas diri mereka sendiri. Sekalipun mereka memerlukan (apa yang mereka berikan itu). Dan siapa yang dipelihara dari kekikiran dirinya, mereka itulah orang-orang yang beruntung." (al-Hasyr: 9)

Seperti yang disebutkan dalam ayat tersebut, orang-orang beriman harus mendahulukan kepentingan saudaranya di atas kepentingan pribadi. Itulah sebenar-benarnya iman: kepatuhan dan persaudaraan.Mendahulukan kepentingan saudaranya tidak terbatas dalam berhubungan dengan hal-hal fisik saja. Ukhuwah juga tidak terpisah dari pemikiran. Seseorang yang beriman harus menyadari kebutuhan dan masalah saudaranya lebih dari dirinya sendiri.

Sikap kasar dan berakhlak buruk menunjukkan kelemahan iman seseorang. Seseorang yang tidak menyadari betapa tindakannya akan memengaruhi orang lain dan berbuat menurut apa yang "dikehendaki" saja, bukanlah contoh orang beriman yang digambarkan Allah. AlQur'an menitikberatkan hal ini dengan beberapa contoh tindakan yang berakhlak mulia maupun yang buruk. Dan yang terpenting adalah dengan memuliakan dan menghormati Rasululah saw. (AlQur'an Terjemah Depaq)

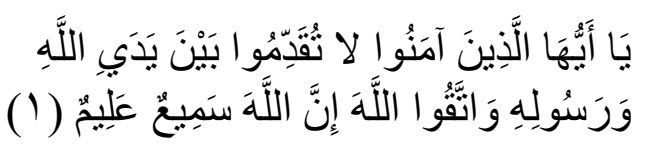


Artinya: "Hai orang-orang yang beriman, janganlah kamu mendahului Allah dan Rasul-Nya dan bertaqwalah kepada Allah. Sesungguhnya, Allah Maha Mendengar lagi Maha Mengetahui." (al-Hujuraat: 1)

Orang yang dibesarkan dengan ajaran al-Qur'an akan menjadi mulia, sopan, santun, dan berakhlak mulia. Inilah sifat alami orang beriman yang mendahului kepentingan saudaranya di atas kepentingan pribadi dan yang memberi makan orang-orang fakir, anak yatim, dan para tahanan karena cinta kepada Allah. Berakhlak mulia menjadi sifat penghuni surga. Tidak mengganggu saudaranya ketika mempunyai urusan penting, berdiam diri ketika temannya sedang shalat, membuat saudaranya merasa aman, menawarkan bantuan dan melayani mereka tanpa bertanya merupakan contoh perbuatan baik. Akan tetapi, semua itu merupakan contoh yang menuntut perubahan situasi dan kondisi.

18. Tidak Mengolok-olok. (Harun Yahya, 2004, p.83)

Ayat berikut secara jelas memberitahukan kepada orangorang beriman agar jangan saling mengolok-olok, Firman Allah SWT:(Al-Qur'an tarjemah Depaq)

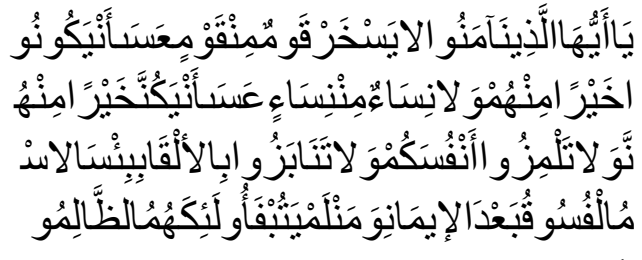

Artinya:"Hai orang-orang yang beriman, janganlah suatu kaum mengolok-olok kaum yang lain (karena) bisa jadi mereka (yang diolok-olok) lebih baik dari mereka (yang mengolok-olok) dan jangan pula wanita-wanita (mengolok-olok) wanita-wanita lain (karena) bisa jadi wanitawanita (yang diperolok-olok) lebih baik dari wanita (yang mengolok-olok) dan janganlah kamu mencela dirimu sendiri dan janganlah kamu panggilmemanggil dengan gelar-gelar yang buruk. Seburuk-buruk panggilan ialah (panggilan) yang buruk sesudah iman dan barangsiapa yang tidak bertobat, maka mereka itulah orang-orang yang zalim." (al-Hujuraat: 11)

Allah menyuruh manusia menahan diri dari mengolok-olok. Mengolok-olok dapat berupa menertawai kemalangan orang lain, tersenyum sinis, menyindir, atau memandang rendah. Sikapsikap seperti itu merupakan budaya orang-orang jahil dan tidak sesuai dengan orang yang beriman dengan sebenarbenarnya.

Al-Qur'an memperingatkan kita bahwa orang yang memperturutkan sikap yang demikian akan menderita karena api neraka akan merambat sampai membakar hati mereka. (Harun Yahya, 2004, p.83), Firman Allah SWT. (Alquran tarjemah Depaq)

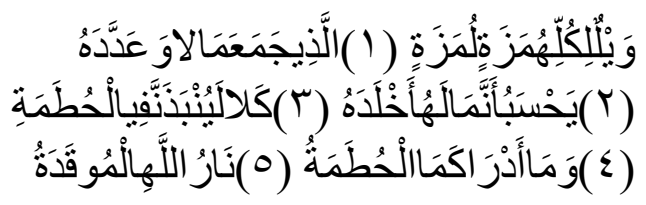




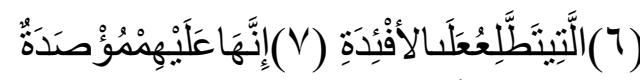

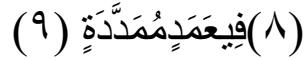

Artinya:"Kecelakaanlah bagi setiap pengumpat lagi pencela, yang mengumpulkan harta dan menghitung-hitungnya, dia mengira bahwa hartanya itu dapat mengekalkannya. Sekalikali tidak! Sesungguhnya, dia benar-benar akan dilemparkan ke dalam Huthamah. Dan tahukah kamu apa Huthamah itu? (Yaitu) api (yang disediakan) Allah yang dinyalakan, yang (membakar) sampai ke hati. Sesungguhnya, api itu ditutup rapat atas mereka, (sedang mereka itu) diikat pada tiang-tiang yang panjang." (alHumazah: 1-9)

19. Tidak Memanggil Orang Beriman dengan Panggilan Buruk. (Harun Yahya, 2004, p.84)

Menjadi kebiasaan bagi orang yang ingkar memanggil orang lain dengan panggilan yang buruk. Maksud sebenarnya dari kebiasaan itu tidak lain adalah untuk merendahkan orang lain dan "membuktikan" kehebatan dirinya sendiri. Panggilan buruk tersebut bisa diambil dari kekurangan fisik ataupun kesalahan di masa lampau. Orangorang yang ingkar tidak akan melupakan kesalahan orang lain meski ia sudah bertobat.

Akan tetapi, orang beriman berbeda dari mereka. Mereka selalu memaafkan dan menjaga persaudaraan di antara mereka. Itulah sebabnya, mereka tidak berbuat seperti itu. Lagi pula Allah telah memerintahkan, "...
Janganlah kamu mencela dirimu sendiri dan janganlah kamu panggil-memanggil dengan gelargelar yang buruk...." (al-Hujuraat: 11)

20. Dapat Dipercaya/Amanah. (Harun Yahya, 2004, p.85)

Al-Qur'an

menggambarkan sifat amanah sebagai salah satu prinsip moral dan jalan menuju kesuksesan. Orang-orang beriman harus menjaga amanat yang dipercayakan kepadanya sampai amanat tersebut dikembalikan. Selain itu, mereka pun harus dapat membedakan siapa yang mengamanatkan dan siapa yang berhak atas amanat tersebut. Dalam hal ini, Al-Qur'an menjelaskan,

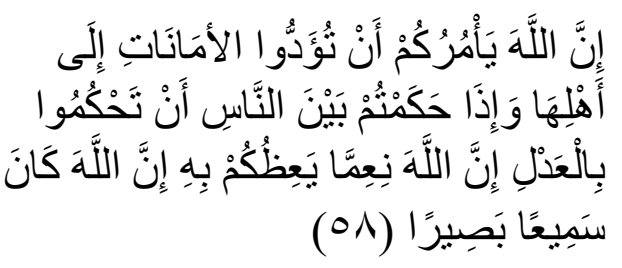

Artinya: "Sesungguhnya, Allah menyuruh kamu menyampaikan amanat kepada yang berhak menerimanya, dan (menyuruh kamu) apabila menetapkan hukum di antara manusia supaya kamu menetapkan dengan adil. Sesungguhnya, Allah memberi pengajaran yang sebaik-baiknya kepadamu. Sesungguhnya, Allah adalah Maha Mendengar lagi Maha Melihat." (an-Nisaa`: 58) Pada ayat lain dijelaskan,

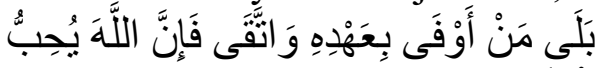

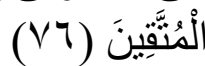
Artinya: "(Bukan demikian), sebenarnya siapa yang menepati janji (yang dibuat)nya dan 
bertaqwa, maka sesungguhnya Allah menyukai orang-orang yang bertaqwa." (Ali Imran: 76)

Anjuran Nabi tentang Amanah:(Ahmad Muhammad, 2015, p.170)

1. "barang pinjaman harus dikembalikan; binatang yang dipinjam untuk diambil manfaatnya, seperti susu, bulu, dan anaknya harus dikembalikan; utang harus dilunasi.

2. "Sampaikanlah barang amanat keada orang yang mengamanatkan kepadamu, dan janganlah engkau berkhianat kepada orang yang berkhianat padamu.

3. "tidak ada iman bagi orang yang tidak memiliki amanah dan tidak ada Agama bagi orang yang tidak mendirikan shalat".

4. "Ada 4 perkara; barang siapa melakukannya maka ia munafik yang komplit. Dan siapa yang melakukann satu dari empat perkara itu, ia mempunyai satu dari empat kemunafikan hingga dia meninggalkannnya, yaitu bila dipercaya dia khianat; bila dia bercerita dia dusta; bila dia berjanji dia tidak menepati; dan bila bertengkar dia mennggalkan yang benar.

5. "Empat perkara bila ada padamu maka tidak mengapalah bagimu bila kamu kehilangan kesenangan dunia; memelihara amanat, benar dalam berkata-kata, baik budi pekerti, dan bersfat Iffah (meninggalkan yang tidak halal.

Akhlak merupakan sisitem nilai yang mengatatur pola sikap dan tindakan manusia diatas muka bumi, sistem nilai yang dimaksud adalah ajaran Islam dengan AlQur'an dan sunah Rosul sebagai sumber nilainya serta ijtihad sebagai metode berfikir. Dengan demikian Ruang lingkup materi pendidikan akhlak yaitu mencakup pola hubungan mansusia dengan diri sendiri, hubungan manusia dengan sesama dan hubungan dengan lingkungan.(Muslim Nurdi, 2001, p.205)

Pendidikan Islam memiliki berbagai macam metode dan sarana diantara sarana-sarana itu ialah sebagi berikut :

a) sarana pertama, membiasakan Akhlak terpuji

b) sarana kedua, teman yang baik

c) sarana ketiga, keteladanan

Relevansi Nilai-Nilai Pendidikan Akhlak dalam Buku Nilai Moral Al-Qur'an Karya Harun Yahya Terhadap pendidikan Islam

Pendidikan akhlak menurut al Qur'an lebih ditekankan pada orang agar mempraktikkan dan mengamalkan nilai-nilai yang baik dan menjauhi nilai-nilai yang buruk dan ditujukan agar manusia mengetahui tentang cara hidup, atau bagaimana seharusnya hidup; karakter (akhlak) menjawab pertanyaan manusia tentang manakah hidup yang baik bagi manusia, dan bagaimanakah seharusnya berbuat, agar hidup memiliki nilai, kesucian dan kemuliaan. 
Akidah adalah gudang akhlak yang kokoh yang dimana mampu menciptakan kesadaran diri bagai Manusia untuk berpegang teguh kepada norma dan nilai-nilai akhlak yang luhur akhlak mendapatkan perhatian istimewa dalam Akidah akhlak. Rasulullah SAW bersabda:

بعثت لاء تمم مك رماكرم الا

Artinya: $A k u$ diutus untuk menyempurnakan Akhlak yang mulia".

Dalam hadist lain beliau bersabda" Akhlak yang mulia adalah setengah dari Agama". (Rosihon Anwar, 2014, p.201)

$\begin{array}{lll} & \text { Ada dua pendekatan yang } \\ \text { dapat } & \text { digunakan } & \text { untuk }\end{array}$ mendifinisikan akhlak, yaitu pendekatan linguistik (kebahasaan), dan pendekatan erminologik (peristilahan). Dari sudut kebahasaan, akhlak berasal dari bahasa arab, yaitu isim mashdar (bentuk infinitive) dari kata akhlaqa,yuhliqu,ikhlaqan, sesuai dengan timbangan (wazan) tsulasi majid af'ala, yuf'ilu, if'alan yang berarti al-sajiyah (perangai), aththaibi'ah (kekuatan, tabi'at, watak dasar), al-'adat (kebiasaan,kelaziman), al- maru'ah (peradaban yang baik), dan al-din (Agama).

(Abuddin Nata, 2015, p.1)

Islam menggabungkan antara Agama yang Haq dan Akhlak.Menurut teori nini agama menganjurkan setiap individu untuk berakhlak mulia dan menjadikannya sebagai kewajiban (taklif) di atas pundaknya yang dapat mendatangkan pahala atau siksa baginya. Atas dasarini, Agama tidak mengutarakan wejangan-wejangan Akhlak semata tampa dibebani oleh rasa tanggung jawab. Bahkan, Agama menganggap Akhlak sebagai penyempurna Ajaranajarannya.Karna Agama tersusun dari keyakinan (Akidah) dan prilaku.Akhlak mencerminkan sisi prilaku tersebut. Imam Bakir a,s berkata:

Artinya: "Mukminin yang paling sempurna Imannya adalah yang paling mulia Akhlaknya". (Rosihon Anwar, 2014, p.201-202)

Menurut Thomas Lickona dalam buku pendidikan karakter karya Agus Wibowo mengatakan bahwa : karater/akhlak merupakan sifat alami seseorang dalam merespons situasi secara bermoral.(Agus Wibowo, 2012, p.32-33) Sifat alami itu dimanifestasikan dalam tindakan nyata melalui tingkah laku baik, jujur, bertanggung jawab, menghormati orang lain dan karakter mulia lainnya. Lickona menekankan tiga hal dalam mendidik karakter atau Akhlak,yaitu : knowing, loving, and acting the Good. Menurutnya keberhasilan pendidikan karakter/akhlak dimulai dengan pemahaman karakter/akhlak yang baik, mencintainya, dan pelaksanaan atau peneladanan atas karakter/akhlak baik.

$$
\text { Menurut Kemendiknas }
$$

(2010), karakter/akhlak adalah watak, tabiat, atau keperibadian seseorang terbentuk dari hasil internalisasi berbagai kebajikanberfikir, bersikap, dan bertindak. Sedangkan pendidikan karakter adalah pendidikan yang mengembangkan nilai-nilai karakter 
bangsa pada diri peserta didik, sehingga mereka memiliki nilai dan karakter sebagai karakter dirinya, menerapkan nilai-nilai tersebut dalam kehidupan dirinya, sebagai anggota masyarakat, dan warga negara yang religius, nasionalisasi, produktif dan kreatif. (Agus Wibowo, 2012, p.35)

Adapun Konsep Manusia yang Ideal dalam Islam, adalah manusia yang kuat imannya dan kuat ketaqwaannya. Ketika Manusia memiliki kekuatan Taqwa, Ia pun dapat memiliki kekuatan ibadah dan kekuatan Akhlak. Orang yang memiliki kekuatan Iman, disebut Mu'min, orang yang memiliki kekuatan ibadah disebut muslim, dan orang yang memiliki kekuatan akhlak disebut muhsin. Bila ketiga macam sifat ini menjadi kekuatan dalam diri setiap manusia, maka ia akan selamat dan bahagia di dunia dan akherat.(Mahjuddin, 2010, p.3

Adapun Ciri-ciri akhlak Islami yang memiliki beberapa keistimewaan dibandingkan dengan Akhlak ciptaan manusia antara lain: (1) Kebajikan yang mutlak.(2) Menyeluruh.(3) Kukuh dan stabil. (4).Niscaya untuk dipatuhi. (Ahmad Muhammad, 2015, p.45)

Akhlak adalah suatu sifat yang tertanam dalam dirimanusia dan bisa bernilai baik atau bernilai buruk. Akhlaktidak selalu identik dengan pengetahuan, ucapan ataupunperbuatan orang yang bisa mengetahui banyak tentang baikburuknya akhlak, tapi belum tentu ini didukung olehkeluhuran akhlak, orang bisa bertutur kata yang lembut danmanis, tetapi kata-kata bisa meluncur dari hati
munafik.Dengan kata lain akhlak merupakan sifat-sifat bawaanmanusia sejak lahir yang tertanam dalam jiwanya dan selaluada padanya Al-Qur'an selalu menandaskan, bahwa akhlak itubaik atau buruknya akan memantul pada diri sendiri sesuaidengan pembentukan dan pembinaannya.(Sukanto,1994, p.80)

Pada dasarnya ada dua aspek kegiatan yang menjadi inti dari pendidikan akhlak.Pertama, pembimbing hati nurani peserta didik agar berkembang lebih positif secara bertahap dan berkesinambungan. Hasil yang diharapkan adalah terjadinya perubahan keperibadian peserta didik yang semula egosentris (berpusat/berstandar pada diri sendiri) menjadi atruis (orang yang mementingkan orang lain dari pada kepentingan dirinya). Keduamemupuk, mengembangkan dan menanamkan nilai-nilai serta sifat-sifat positif kedalam pribadi peserta didik, dan bersama dengan upaya pemupukan nilai-nilai positif ini, pendidikan akhlak berupaya mengikis dan menjauhkan peserta didik dari sifat-sifat nilai buruk.Dengan demikian, titik tekan pendidikan akhlak adalah untuk mengembangkan potensi-potensi kreatif yang positif dari serta didik agar menjadi manusia yang baik. (Juwariyah, 2010, p.15)

Ajaran akhlak menemukan bentuknya yang sempurna pada ajaran Agama Islam dengan titik pangkalnya pada Tuhan dan akal Manusia.aAgama Islam pada intinya mengajak manusia agar percaya kepada Tuhan dan mengakuinya bahwa Dialah pencipta, Pemilik, 
pemelihara, pelindung, pemberi Rahmat, pengasih dan penyayang terhadap makhluknya. Segala apa yang ada di dunia ini, dari gejalagejala yang bermacam-macam dan segala makhluk yang beraneka warna, dari biji dan binatang yang melata dibumi sampai kepada langit yang berlapis semuanya milik Tuhan, dan diatur oleh-Nya.(Abuddin Nata, 2015, p.57)

Sedangkan ruang lingkup Akhlak yang islami ada tiga yaitu: 1). Akhlak terhadap Allah SWT. 2). Akhlak terhadap sesama Manusia. 3). Akhlak terhadap lingkungan. (Abuddin Nata, 2015, p.57)

Uraian diatas sangat sesuai dengan pembahasan yang terdapat didalam buku Nilai-Nilai Moral alQur'an karya Harun Yahya, yang dimana semua pembahasannya tidak terlepas dari bagaimana Manusia harus berusaha menjadi Insan yang berakhlak mulia sesuai dengan Alqur'an dan hadist yang dimana tolak ukur dari baik atau buruknya seorang itu mengacu pada baik atau buruk yang ada pada keseluruhan ajaran Agama yang bertumpu dan berpondasikan Al-qur' an dan Sunnah Nabi (hadist), yang dimana pendidikan Islam ialah mengacu pada bagaimana Manusia itu menjadi manusia yang baik menurut sudut pandang Agama.

\section{Kesimpulan}

Nilai-nilai pendidikan akhlak dalam buku "Nilai Moral Al-Qur'an" karya Harun Yahya adalah Keberadaan Allah (Berakhlaq melalui meyakini keberadaan Allah.), Taqwa kepada Allah SWT,
Takdir. (Mengimani takdir Allah), Iman kepada Allah, Berdo'a, Penyesalan dan Memohon Ampun, Sabar, Menilai Segala Sesuatu Dengan Cara Pandang Al-Qur'an, Bersyukur Kepada Allah, Tidak Ada Yang Lebih Dicintai Daripada Allah Dan Rasul-Nya Serta Berjihad Di Jalan-Nya, Tidak Lemah, Bersedih Hati, dan Berputus Asa, Merendahkan Diri Ketika Shalat, Bertasbih Memuji Allah SWT, Mengingat Allah dalam Setiap Kesulitan, Membaca Wahyu Allah SWT, Berlindung kepada Allah dari Godaan Setan Ketika Membaca alQur`an, Rendah Hati, Tidak Mengolok-olok, Tidak Memanggil Orang Beriman dengan Panggilan Buruk dan Dapat Dipercaya/Amanah. Sedangkan ruang lingkup Akhlak yang islami ada tiga yaitu: 1). Akhlak terhadap Allah SWT. 2). Akhlak terhadap sesama Manusia. 3). Akhlak terhadap lingkungan.

Relevansi Nilai-Nilai

Pendidikan Akhlak dalam Buku Nilai Moral Al-Qur'an Karya Harun Yahya Terhadap pendidikan Islam, Pendidikan akhlak menurut al Qur`an lebih ditekankan pada Manusia agar mempraktikkan dan mengamalkan nilai-nilai yang baik dan menjauhi nilai-nilai yang buruk dan ditujukan agar manusia mengetahui tentang cara hidup, atau bagaimana seharusnya hidup; karakter (akhlak) menjawab pertanyaan manusia tentang manakah hidup yang baik bagi manusia, dan bagaimanakah seharusnya berbuat, agar hidup memiliki nilai, kesucian dan kemuliaan. Adapun Ciri-ciri akhlak Islami yang memiliki beberapa 
keistimewaan dibandingkan dengan Akhlak ciptaan manusia antara lain: (1) Kebajikan yang mutlak.(2) Menyeluruh.(3) Kukuh dan stabil. (4).Niscaya untuk dipatuhi. Ajaran akhlak menemukan bentuknya yang sempurna pada ajaran Agama Islam dengan titik pangkalnya pada Tuhan dan akal Manusia. Agama Islam pada intinya mengajak manusia agar percaya kepada Tuhan dan mengakuinya bahwa Dialah pencipta, Pemilik, pemelihara, pelindung, pemberi Rahmat, pengasih dan penyayang terhadap makhluknya. Segala apa yang ada di dunia ini, dari gejala-gejala yang bermacam-macam dan segala makhluk yang beraneka warna, dari biji dan binatang yang melata dibumi sampai kepada langit yang berlapis semuanya milik Tuhan, dan diatur oleh-Nya.

\section{DAFTAR PUSTAKA}

Undang-undang RI Nomor 20 Tahun 2003 Tentang Sistem Pendidikan Nasional, Jakarta:Cemerlang, 2003.

Arifin, HM., 1976,Hubungan Timbal Balik Pendidikan Agama, Jakarta: Bulan Bintang

Marimba, Ahmad D, 1989, Pengantar Filsafat

Pendidikan, Bandung: Al Ma'arif

Lasmawan, Wayan, 2004, Pengembangan Materi Dan Model Pendidikan Karakter Berbasiss Budaya Dalam Konteks Instruksional Aplikasi Dalam Pembelajaraan Siswa Jenjang SMP, Tk: Undiksha, priode pendidikan Ips
Ramayulis, Ilmu Pendidikan Islam, Jakarta: Kalam mulia, 2004.

Majid et. Al, Abdul, Pendidikan Karakter Dalam Perspektif Islam, Bandung: Remaja Rosda karya.

W.JS. Purwadarminta, Kamus Umum Bahasa Indonesia, Jakarta: Balai Pustaka,

1999.

H. Titus, M.S, et al, PersoalanPersoalan Filsafat, Jakarta: Bulan Bintang, 1984.

Juwariyah, Dasar Dasar Pendidikan Anak Dalam Al-Qur'an, Yogyakarta : Teras, 2010.

Tatapangarsa, Humaidi, Pengantar Kuliah Akhlak, Surabaya : Bina Ilmu, 1990.

Yahya, Harun, Berfikir Sejak Anda Bangun Tidur, terj: Sunarsih, dkk., Jakarta : Globalmedia Cipta Publishing, 2004.

Yahya, Harun, Nilai-Nilai Moral AlQur'an terj: Sunarsih, dkk., Jakarta: Globalmedia Cipta Publishing, 2004.

D. Marimba, Ahmad, Pengantar Filsafat Pendidikan Islam, Bandung: PT Al-Ma'arif, 1980.

Al-Abrasyi, M. Athiyah, Dasardasar Pokok Pendidikan Islam, Jakarta; Bulan Bintang, 1970.

Departemen Pendidikan dan kebudayaan, Kamus Besar Bahasa Indonesia, Jakarta: Balai pustaka, 1994.

Yahya, Harun, 2004. Nilai-Nilai Moral Al-Qur'an terj: Sunarsih, dkk., Jakarta: Globalmedia Cipta Publishing. 
Abdul Majid dan Dian Andayani, Pendidikan agama islam Berbasis Kompetensi (Konsep dan Impelementasi kurikulum 2004), Bandung: PT Remaja Rosdakarya, 2005.

Muhammad, Ahmad, Rujukan Induk Akhlak Rasulullah, Terjemahan dari Min Akhlaqin Nabi. Mesir: Pustaka Akhlak 2015.

Nurdi, Muslim, Etika Ilmu akhlak, Jakarta : Bulan Bintang 2001.

Anwar, Rosihon, Akidah Akhlak, Bandung: Pustaka Setia, 2014.

Nata, Abuddin, Akhlak Tasawuf dan Karakter Mulia, Jakarta: Raja Grafindo persada, 2015.

Wibowo, Agus, Pendidikan Karakter, Yogyakarta: Pustaka Pelajar, 2012.

Mahjuddin, Akhlak Tasawuf II, Jakarta: Kalam Mulia 2010.

Muhammad, Ahmad, Rujukan Induk Akhlak Rasulullah, Terjemahan dari Min Akhlaqin Nabi. Mesir: Pustaka Akhlak 2015.

Sukanto, Paket Moral Islam Menahan Nafsu dari Hawa, Solo: Maulana 1994.

Juwariyah, Dasar-Dasar Pendidikan Anak dalam Al-Qur'an, Yogyakarta: Teras, 2010.

Nata, Abuddin, Akhlak Tasawuf dan Karakter Mulia, Jakarta: Raja Grapindo Persada, 2015. 